\title{
NITRATOS E METAIS PESADOS NO SOLO E EM PLANTAS DE Eucalyptus grandis APÓS APLICAÇÃO DE BIOSSÓLIDO DA ETE DE BARUERI
}

\author{
CRISTIANO ALBERTO DE ANDRADE \\ Engenheiro Agrônomo
}

Orientador: Prof ${ }^{\mathrm{a}}$ Dra. MARIA EMÍLIA MATTIAZZO-PREZOTTO

Dissertação apresentada à Escola Superior de Agricultura "Luiz de Queiroz", Universidade de São Paulo, para obtenção do título de Mestre em Agronomia, Área de Concentração: Solos e Nutrição de Plantas.

PIRACICABA

Estado de São Paulo - Brasil

Dezembro - 1999 


\section{Dados Internacionais de Catalogação na Publicação (CIP) DIVISÃo DE BIBLIOTECA E DOCUMENTAÇÃO - Campus "Luiz de Queiroz"/USP}

Andrade, Cristiano Alberto de

Nitratos e metais pesados no solo e em plantas de Eucalyptus grandis após aplicação de biossólido da ETE de Barueri / Cristiano alberto de Andrade. - - Piracicaba, 1999.

$65 \mathrm{p}$.

Dissertaçāo (mestrado) - - Escola Superior de Agricultura Luiz de Queiroz, 1999.

Bibliografia

1. Eucalipto 2. Lixiviação do solo 3. Lodo de esgoto 4. Metal pesado 5 . Nitrato 6. Solo I. Título

CDD 634.9734

'Permitida a cópia total ou parcial deste documento, desde que citada a fonte - 0 Autor 
A DEUS, humildemente,

OFEREÇO.

Aos meus pais, Antonio e Rute, e meu irmão Cassio, pelas alegrias, pelo apoio, incentivo e amor,

DEDICO. 


\section{AGRADECIMENTOS}

À Prof ${ }^{a}$. Dra. Maria Emília Mattiazzo-Prezotto, pela orientação, apoio e, acima de tudo, pela amizade;

Aos meus tios, Bolivar e Rosimeire, e ao meu primo Evandro; pelo apoio constante;

À Ana Carla Lima, pelo incentivo, e por todos momentos felizes que passamos;

Aos "irmãos" de república, Roberto, Luis Pedro e Luciano, por todos os momentos alegres, pelo companherismo e amizade;

Aos amigos Adriana, Silvino, Aderbal, Márcia e Fernando, pela amizade sincera e apoio em todos os momentos;

A Luis e Marcelino, pela importante colaboração na execução das atividades de campo, e pela amizade sincera;

Aos Professores Fábio Poggiani e José Leonardo, pelas importantes sugestões na elaboração do presente trabalho;

Ao Engenheiro Florestal do IPEF Vanderlei Benedetti pelo apoio e amizade;

Às secretárias Angélica, Armelinda, Márcia, Geovana e Nanci, pela gentileza e atenção constantes;

Aos funcionários e estagiários do Departamento de Ciências Exatas da ESALQ/USP Área de Química analítica, Lenita, Janaína, Carlos, Daniel, Fernanda e Maurício, pela importante colaboração na execução das análises laboratoriais; 
Aos funcionários da Estação Experimental da ESALQ/USP em Itatinga, pelo apoio e atenção dispensados;

Aos funcionários do laboratório de Ecologia Aplicada do Departamento de Engenharia Florestal da ESALQ/USP, pela cooperação;

Aos colegas do curso de Solos e Nutrição de Plantas, pela convivência agradável;

À coordenação do curso de Pós-Graduação em Solos e Nutrição de Plantas da ESALQ/USP, pela oportunidade concedida;

A SABESP, pelo apoio financeiro para execução do trabalho;

A CAPES, pela concessão de bolsa no biênio 1998/99;

Finalmente, a todos aqueles que direta ou indiretamente colaboraram para a realização deste trabalho. 


\section{SUMÁRIO}

RESUMO

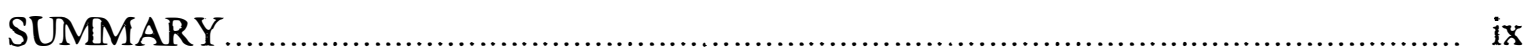

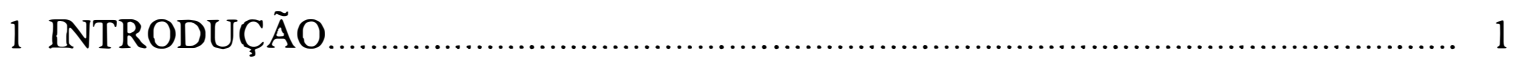

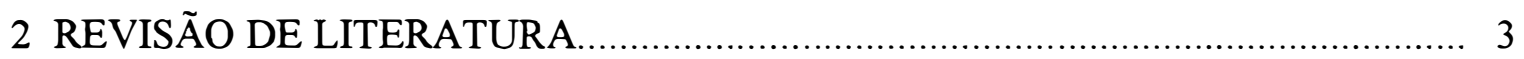

2.1 Matéria orgânica e macronutrientes no biossólido................................................ 3

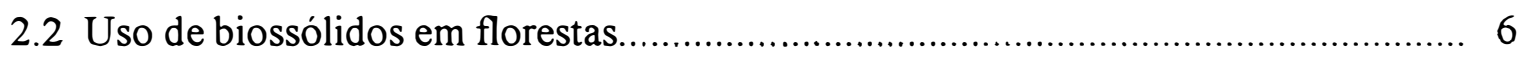

2.3 Metais pesados em biossólidos, fitodisponibilidade e lixiviação no solo................. 8

2.4 Aspectos da legislação ligados a metais pesados no biossólido.............................. 12

2.5 Taxa de mineralização do nitrogênio do biossólido e lixiviação de nitrato.............. 13

3 MATERIAL E MÉTODOS ............................................................................ 20

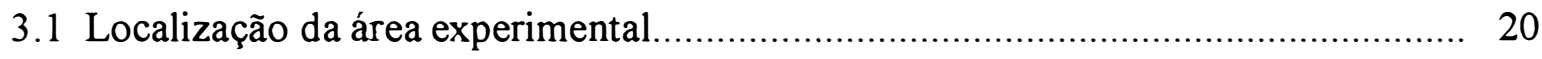

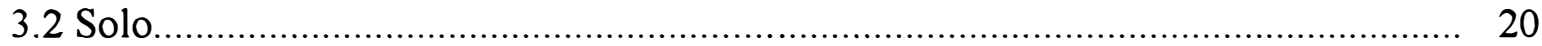

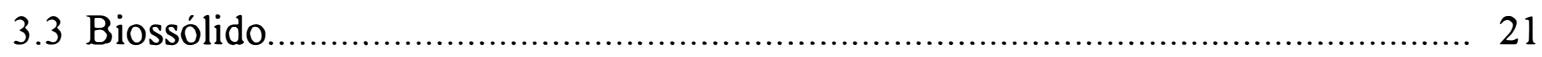

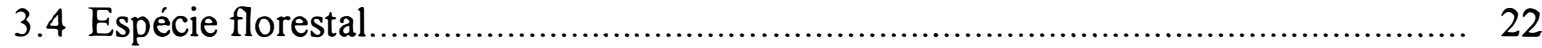

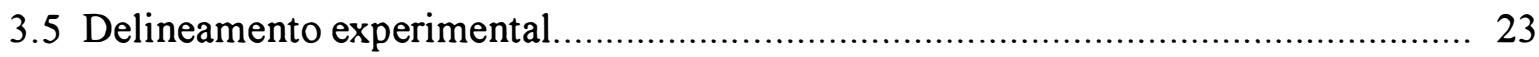

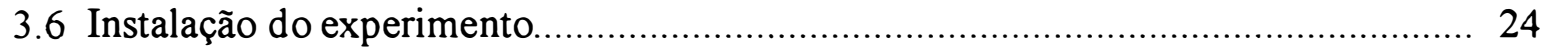

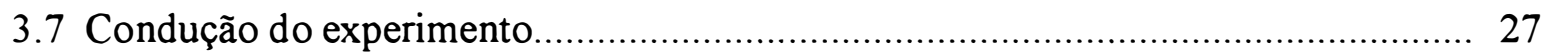

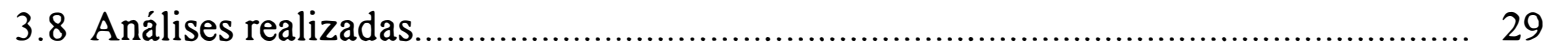

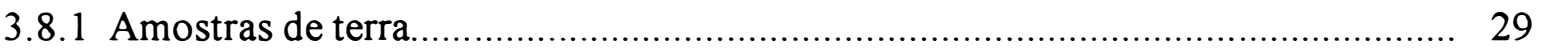

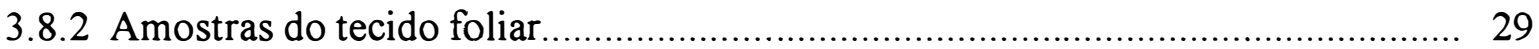

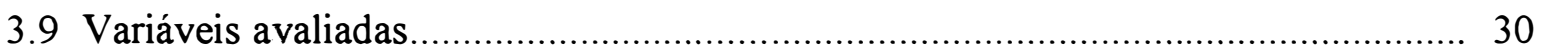

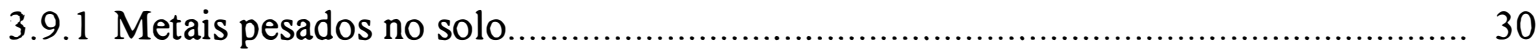

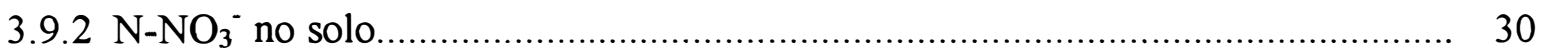

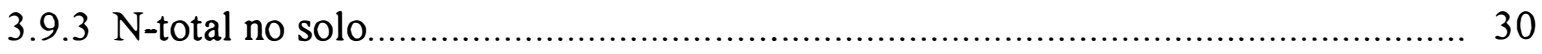

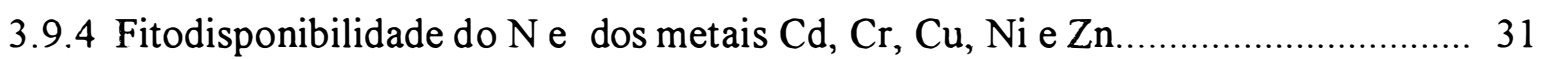

3.10 Tratamento estatístico dos dados obtidos.................................................... 31

3.10.1 Dados obtidos até 180 dias após aplicação do biossólido................................ 31 
3.10.2 Dados obtidos 360 dias após aplicação do biossólido...................................... 32

4 RESULTADOS E DISCUSSÃO.......................................................................... 33

4.1 Metais pesados no solo .......................................................................... 35

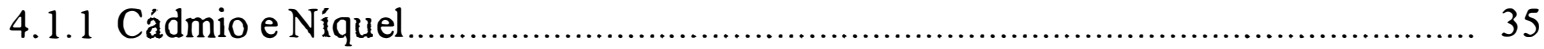

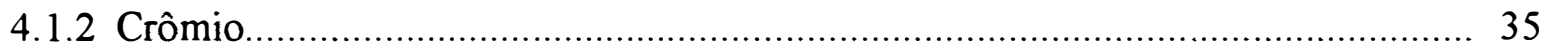

4.1.3 Cobre

4.1.4 Zinco

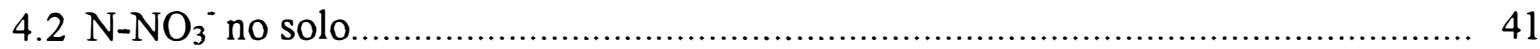

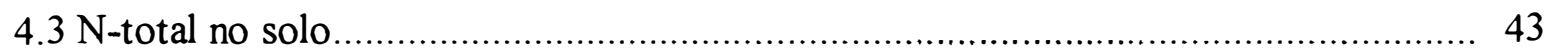

4.4 Fitodisponibilidade dos metais pesados ........................................................ 44

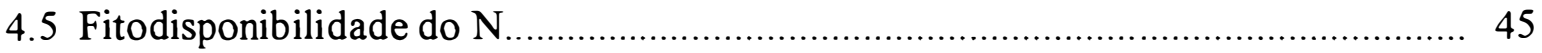

5 APRECIAÇÃO GERAL DOS RESULTADOS OBTIDOS ...................................... 47

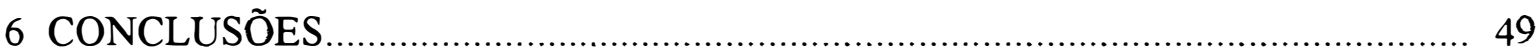

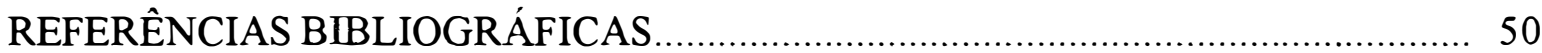

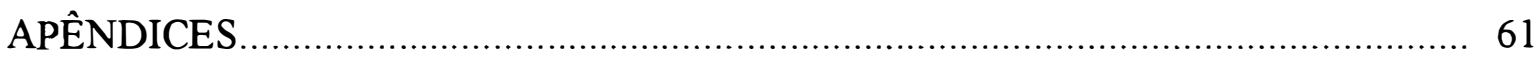




\title{
NITRATOS E METAIS PESADOS NO SOLO E EM PLANTAS DE Eucalyptus grandis APÓS APLICAÇÃO DE BIOSSÓLIDO DA ETE DE BARUERI
}

\author{
Autor: Cristiano Alberto de Andrade \\ Orientador: Prof ${ }^{\natural}$. Dra. Maria Emília Mattiazzo-Prezotto
}

\section{RESUMO}

O uso de biossólidos na agricultura tem sido proposto como forma de disposição final deste resíduo, pela reciclagem dos nutrientes nele contido, e por funcionar como condicionador de solos em função de seu conteúdo orgânico. Entretanto, diversas dúvidas ainda permanecem sobre o impacto real dessa prática sobre o ambiente, principalmente no que diz respeito a contaminação de solos e plantas por metais pesados, e de águas subterrâneas por nitratos.

Este trabalho teve como objetivos estudar a movimentação $\mathrm{e}$ fitodisponibilidade de $\mathrm{N}$ e dos metais pesados $\mathrm{Cd}, \mathrm{Cr}, \mathrm{Cu}$, $\mathrm{Ni}$ e $\mathrm{Zn}$ num Latossolo Vermelho-Amarelo textura arenosa em função da aplicação de doses crescentes de biossólido proveniente da ETE-Barueri / SABESP, Barueri-SP.

$\mathrm{O}$ biossólido úmido $\left(615,2 \mathrm{~g} \mathrm{~kg}^{-1}\right)$ foi aplicado nas doses de $10,20 \mathrm{e}$ $40 \mathrm{Mg} \mathrm{ha}^{-1}$ (base seca), em faixa nas entrelinhas de plantio, sem incorporação, em uma área recém plantada (4 meses) com Eucalyptus grandis. Aos 30, 60, 120 e 180 dias após a aplicação do biossólido foram coletadas amostras de terra nas profundidades 0-30, 3060 e 60-90 cm para determinação dos teores de $\mathrm{N}^{-\mathrm{NO}_{3}}{ }^{-}$e dos metais $\mathrm{Cd}, \mathrm{Cr}, \mathrm{Cu}, \mathrm{Ni}$ e 
Zn removidos pelo extrator Mehlich 3. Aos 360 dias da aplicação do biossólido, a amostragem do solo foi realizada nas profundidades de 0-10, 10-20, 20-30, 30-60 e 60-90 cm, e nessas amostras, além das determinações feitas nas outras épocas, também foram determinados teores totais de $\mathrm{N}$ e dos metais extraídos com água régia. Amostras de folhas também foram coletadas nessa ocasião para avaliação da fitodisponibilidade do $\mathrm{N}$ e metais aplicados via biossólido.

A aplicação das doses de biossólido não alterou o teor de $\mathrm{N}$-total e $\mathrm{N}^{-\mathrm{NO}_{3}}{ }^{-}$no solo nas várias profundidades estudadas, porém o teor de $\mathrm{N}$ nas folhas aumentou linearmente com o $\mathrm{N}$ aplicado via biossólido, o que evidencia um efeito das doses de biossólido sobre a fitodisponibilidade do $\mathrm{N}$ no solo. Dentre os metais analisados, os teores de $\mathrm{Cd}$ e $\mathrm{Ni}$ no solo estiveram abaixo do limite de determinação do método analítico utilizado. Os resultados dos teores de $\mathrm{Cu}$ removido pelo extrator Mehlich 3 mostraram aumento na camada $0-10 \mathrm{~cm}$, entretanto, os teores totais do elemento não foram alterados com as doses de biossólido. Os teores totais de $\mathrm{Cr}$ e $\mathrm{Zn}$ no solo foram afetados de forma diferente pelo biossólido aplicado nas diferentes doses: $\mathrm{Cr}$ acumulou na camada 0-10 cm e $\mathrm{Zn}$ na camada $30-60 \mathrm{~cm}$ do solo. Não foi observado efeito do biossólido sobre as concentrações de $\mathrm{Cd}, \mathrm{Cr}, \mathrm{Cu}, \mathrm{Ni}$ e $\mathrm{Zn}$ nas folhas de E. grandis durante o período experimental.

A aplicação do biossólido em doses de até $40 \mathrm{Mg} \mathrm{ha}^{-1}$ não provocou movimentação de nitratos e nem dos metais $\mathrm{Cd}, \mathrm{Cu}, \mathrm{Cr}$ e $\mathrm{Ni}$ no solo. Não houve evidências de fitodisponibilidade dos metais estudados, porém foi comprovado aumento na disponibilidade de $\mathrm{N}$ às plantas de E. grandis em função das doses crescentes de biossólido aplicadas. Entretanto resultados mais conclusivos somente serão possíveis ao longo dos anos, tendo em vista a espécie utilizada e a forma de aplicação do biossólido. 


\title{
NITRATES AND HEAVY METALS IN THE SOIL AND IN PLANTS OF Eucalyptus grandis AFTER APPLICATION OF BIOSOLIDS OF ETE OF BARUERI
}

\author{
Author: Cristiano Alberto de Andrade \\ Adviser: Prof ${ }^{a}$. Dra. Maria Emília Mattiazzo-Prezotto
}

\section{SUMMARY}

The biosolids use in the agriculture has been proposed as a final form of disposition of this residue. What is more, this practice recycles nutrients and conditioners soils, in function of its organic matter content. However, several doubts still stay about the real environmental impact of this practice, mainly about the soil and plants contamination with heavy metals, and also of underground waters with nitrates.

The aim of this work is to study the movementation and availability of $\mathrm{N}$ and heavy metals ( $\mathrm{Cd}, \mathrm{Cr}, \mathrm{Cu}, \mathrm{Ni}$ and $\mathrm{Zn}$ ) to Eucalyptus grandis in a Typic Hapludox (sandy soil), in function of biosolid application rates. The biosolid used was from ETE-Barueri / SABESP, Barueri-SP.

The humid biosolids $\left(615,2 \mathrm{~g} \mathrm{~kg}^{-1}\right)$ was applied in the rates of 10,20 and 40 $\mathrm{Mg} \mathrm{ha}^{-1}$ (dry weight basis), in interows spaces, without incorporation, in a recently planted area (4 months) with Eucalyptus grandis. At the 30, 60, 120 and 180 days after the biosolids application soil samples were collected in the depths 0-30, 30-60 and 60-90 $\mathrm{cm}$ for determination of $\mathrm{N}_{-} \mathrm{NO}_{3}{ }^{-}$concentrations and of the metals $\mathrm{Cd}, \mathrm{Cr}, \mathrm{Cu}, \mathrm{Ni}$ and $\mathrm{Zn}$ 
removed by the Mehlich 3 extractant. In the 360 days after biosolids application, the soil sampling was accomplished in the depths of $0-10,10-20,20-30,30-60$ and $60-90 \mathrm{~cm}$. In these samples, were done the same determinations and total $\mathrm{N}$ concentrations and of the metals removed by acqua regia extractant. Samples of leaves of $E$. grandis trees were also collected on that occasion for evaluation of the bioavailability of $\mathrm{N}$ and heavy metals.

The biosolids application rates did not alter the N-total and $\mathrm{N}_{-} \mathrm{NO}_{3}{ }^{-}$ concentration in the soil, although the $\mathrm{N}$ concentration in the leaves increased lineally with biosolids rates applied. This fact evidences an effect of the biosolids rates on the availability of $\mathrm{N}$ to E. grandis trees. The soil concentrations of $\mathrm{Cd}$ and $\mathrm{Ni}$ were below the limit of determination of the analytic method used. The results of the $\mathrm{Cu}$ concentrations removed by Mehlich 3 extractant showed increase in the layer $0-10 \mathrm{~cm}$, however, the total concentration of the element were not altered with the biosolids rates. The total soil concentrations of $\mathrm{Cr}$ and $\mathrm{Zn}$ were affected in a different way for the biosolids applied rates: $\mathrm{Cr}$ accumulated in the layer $0-10 \mathrm{~cm}$ and $\mathrm{Zn}$ in the layer 30-60 $\mathrm{cm}$ of the soil. The effect of biosolids addition was not verified for $\mathrm{Cd}, \mathrm{Cr}, \mathrm{Cu}, \mathrm{Ni}$ and $\mathrm{Zn}$ concentrations in the $E$. grandis leaves during the experimental period.

The biosolids application rates (10 to $40 \mathrm{Mg} \mathrm{ha}^{-1}$ ) did not alter nitrates and $\mathrm{Cd}$, $\mathrm{Cu}, \mathrm{Cr}$ and $\mathrm{Ni}$ movement in the soil profile depth. There were not evidences of the studied metals bioavailability, but it was proven increase in the readiness of $\mathrm{N}$ to the $E$. grandis trees in function of the biosolids application rates. Conclusive results will only be possible along of the years, because of the used specie and the biosolids application form. 


\section{INTRODUÇÃO}

Os resíduos gerados pela atividade industrial e pela população constituem problema emergencial nos dias atuais e dentre esses resíduos merecem destaque os esgotos, não somente pelo grande volume produzido diariamente, mas também pelas formas inadequadas de descarte, poluindo rios e o oceano.

Para amenizar o problema, diversas cidades tem promovido o ratamento de seus esgotos reduzindo sua carga orgânica e o potencial poluente devido a esse material. Entretanto, com o tratamento dos esgotos há geração de um novo resíduo, o lodo de esgoto, cuja disposição final é problema dos mais sérios, representando cerca de $56 \%$ das despesas operacionais das Estações de Tratamento (ETEs). A disposição final do lodo em aterros sanitários, além do custo envolvido, esbarra na disponibilidade restrita de áreas adequadas para instalações de aterros próximos a grandes centros urbanos.

Alternativas para disposição final do lodo de esgoto tem sido propostas e, dentre elas, surge o uso agrícola desse lodo ou biossólido que tem como benefícios a reciclagem dos nutrientes nele contido e sua ação como condicionador do solo, função de seu conteúdo orgânico. Além de representar um benefício social (descarte menos impactante do resíduo), a reciclagem na agricultura pode representar um benefício de ordem econômica, pela redução nos gastos com a compra de insumos.

Os efeitos benéficos do uso agrícola do biossólido tem sido atestados por diversos pesquisadores, mas esse material pode apresentar, em função da sua composição, características indesejáveis sob o ponto de vista agronômico, tais como: presença de organismos patogênicos, materiais orgânicos recalcitrantes, elevadas concentrações de sais solúveis e metais pesados. O estudo mais detalhado de características do biossólido e seu impacto sobre o sistema de produção agrícola se faz 
necessário para a obtenção de parâmetros que regulem seu uso em áreas agrícolas, particularmente no que se refere a dose e freqüência de aplicação.

Nos últimos anos muita atenção tem sido dada aos metais pesados existentes no biossólido que poderiam poluir o solo e por lixiviação contaminar águas subterrâneas, além de poderem eventualmente entrar na cadeia alimentar causando danos à saúde humana e animal. Nesse último aspecto, o uso do biossólido em plantios florestais para produção de celulose, papel e madeira, torna-se atraente. No Brasil existem trabalhos desenvolvidos com o intuito de estudar o efeito do biossólido em áreas agrícolas, no entanto não se encontraram trabalhos com espécies florestais de rápido crescimento.

Outro aspecto que nem sempre é considerado, mas de suma importância quando se cogita o uso agronômico do biossólido, diz respeito ao nitrogênio (N) aplicado via resíduo. Em função da taxa de mineralização do $\mathrm{N}$ (TMN), que é dependente de características do biossólido e do solo onde é aplicado, pode haver movimentação de nitrato no perfil do solo e conseqüente contaminação de águas subterrâneas. O comportamento do $\mathrm{N}$ aplicado via resíduos orgânicos, em geral, ou biossólidos, em particular, tem sido pouco estudado em solos ácidos e muito intemperizados.

O presente trabalho teve como objetivo principal avaliar a eficiência do biossólido proveniente da ETE-Barueri/SABESP como fornecedor de nutrientes e elementos potencialmente tóxicos para uma espécie florestal de rápido crescimento num Latossolo Vermelho-Amarelo textura arenosa. Os objetivos específicos foram:

- Avaliar a movimentação dos metais pesados $\mathrm{Cd}, \mathrm{Cr}, \mathrm{Cu}, \mathrm{Ni}$ e $\mathrm{Zn}$ no perfil vertical do solo;

- Avaliar a movimentação de $\mathrm{N}_{-} \mathrm{NO}_{3}{ }^{-}$no perfil vertical do solo;

- Avaliar a disponibilidade do $\mathrm{N}$ e dos metais pesados $\mathrm{Cd}, \mathrm{Cr}, \mathrm{Cu}, \mathrm{Ni}$ e Zn às plantas de Eucalyptus grandis. 


\section{REVISÃO DE LITERATURA}

\subsection{Matéria orgânica e macronutrientes no biossólido}

Lodo de esgoto ou biossólido pode ser definido como um resíduo semi-sólido predominantemente orgânico, com teores variáveis de componentes inorgânicos, originado do tratamento de águas residuais domiciliares e/ou industriais. A origem do esgoto e o processo de tratamento utilizado são os principais responsáveis pelas variações na composição química de biossólidos.

Em função do conteúdo orgânico, tem sido propostas aplicações de biossólido como método para manutenção dos níveis de matéria orgânica em áreas agrícolas, bem como em florestas e áreas degradadas (Boyle \& Paul, 1989 e Diaz-Burgos \& Polo, 1991). Em regiões de clima tropical e subtropical onde a matéria orgânica adquire papel fundamental na CTC, o uso de biossólido na agricultura torna-se ainda mais atrativo (Melo et al.,1994). A influência da fração orgânica de doses de biossólido superiores a $30 \mathrm{Mg} \mathrm{ha}^{-1}$ na CTC de solos, é significativa por um período que varia de 230 a 300 dias após sua aplicação (Melo et al., 1997).

Informações acerca do tipo de matéria orgânica presente no biossólido ainda são escassas. Alguns trabalhos tem sido desenvolvidos no sentido de estudar a cinética da degradação do material orgânico do biossólido; dentre os existentes pode-se citar o de Barreto (1995) que estudou a degradação da fração orgânica de um biossólido ( $\mathrm{pH}=$ 10,$1 ;$ umidade $=732,5 \mathrm{~g} \mathrm{~kg}^{-1} ; \mathrm{N}$-total $=24,3 \mathrm{~g} \mathrm{~kg}^{-1}$ ) incorporado nas doses de $18,9 \mathrm{e}$ $37,7 \mathrm{Mg} \mathrm{ha}^{-1}$ a dois solos (Latossolo Vermelho Escuro - LE e Areia Quartzoza - AQ). $O$ autor não encontrou diferenças para as taxas de degradação da fração orgânica adicionada via biossólido, em função do tipo de solo. A taxa de degradação média dos 
dois solos para menor dose de biossólido, num período de 60 dias, foi de 30,6\% e para a maior dose, $26,0 \%$.

Mattiazzo et al. (1998) utilizando os dados de respirometria obtidos por Barreto (1995) encontraram valores de 0,0082 e 0,0087 $\mathrm{dia}^{-1}$, para as constantes de velocidade da reação de degradação da fração orgânica do biossólido, aplicado na menor dose (18,9 $\mathrm{Mg} \mathrm{ha}{ }^{-1}$ ) respectivamente aos solos LE e AQ. Na maior dose de biossólido (37,7 $\mathrm{Mg} \mathrm{ha}^{-1}$ ) as constantes de velocidade foram 0,0058 e 0,0064 $\mathrm{dia}^{-1}$ para LE e AQ, o que indica que a velocidade de degradação do conteúdo orgânico do biossólido diminui com o aumento da quantidade adicionada ao solo, sendo possível o acúmulo de materiais orgânicos recalcitrantes no solo com aplicação freqüente de biossólido.

Além da matéria orgânica o biossólido possui elementos e compostos inorgânicos importantes para plantas e animais. Ainda não fơi realizada uma caracterização generalizada para teores de macronutrientes em biossólidos em nosso país, mas alguns usados em trabalhos de pesquisa no Estado de São Paulo foram reunidos na Tabela 1.

Tabela 1 Teores totais de N, P, K, Ca, Mg e S em bissólidos utilizados em alguns experimentos desenvolvidos no Estado de São Paulo. Resultados expressos em base seca.

\begin{tabular}{ccccccc}
\hline $\mathrm{N}$ & $\mathrm{P}$ & $\mathrm{K}$ & $\mathrm{Ca}$ & $\mathrm{Mg}$ & $\mathrm{S}$ & Fonte \\
\hline$\cdots 12,6$ & 11,7 & 2,6 & $*$ & 6,0 & $*$ & Bettiol (1982) \\
13,8 & 8,6 & 2,2 & 15,7 & 6,2 & 1,0 & Berton et al. (1989) \\
7,2 & 5,9 & 1,3 & 25,7 & 4,3 & $*$ & Melo et al. (1994) \\
8,3 & 2,1 & 0,3 & 36,9 & 0,8 & 5,2 & Oliveira (1995) \\
21,4 & 10,0 & 2,4 & 15,6 & 2,7 & 34,9 & Oliveira et al. (1995) \\
22,9 & 20,2 & 1,5 & 11,8 & 3,3 & 8,8 & Bertoncini (1997) \\
16,0 & 8,0 & 1,6 & 20,0 & $*$ & $*$ & Berton et al. (1997) \\
19,0 & 11,0 & 1,1 & 132,0 & 4,0 & $*$ & Pires (1998) \\
4,2 & 2,8 & 3,9 & 3,5 & 8,6 & $*$ & Melo et al. (1998) \\
9,4 & 7,9 & 1,6 & 136,0 & 3,7 & $*$ & Anjos (1999) \\
\hline
\end{tabular}

* Valores não fornecidos. 
Nitrogênio e fósforo são encontrados nos biossólidos, com valores médios de respectivamente 21,2 e $9,9 \mathrm{~g} \mathrm{~kg}^{-1}$. Ayuso et al. (1992) relataram que o fósforo do bissólido, proveniente em grande parte de detergentes (polifosfatos), quando da aplicação no solo promoveria um acréscimo no teor do elemento, acabando por incrementar também sua absorção. No entanto, Pires (1998) e Anjos (1999) observaram que, apesar do incremento do teor do elemento no solo com a aplicação de biossólido, houve necessidade de adubação com fertilizante fosfatado inorgânico, respectivamente para plantas de arroz e milho.

No caso do potássio o biossólido é deficiente (Bunting, 1963), exigindo complementação potássica (Da Ros et al.,1993 e Oliveira et al., 1995).

Os teores de cálcio e ferro no biossólido podem ser muito elevados, principalmente se no processamento da ETE for usado cal e cloreto férrico.

As concentrações de magnésio no biossólido são geralmente menores que as de cálcio e, quando solos recebem biossólido com alta relação $\mathrm{Ca} / \mathrm{Mg}$, caso de biossólidos tratados com cal, perdas consideráveis de $\mathrm{Mg}^{+2}$ por lixiviação podem ocorrer (Anjos, 1999), o que agrava o problema de desbalanço de nutrientes no solo e nas plantas.

Quanto ao enxofre, poucas informações se tem sobre as concentrações desse nutriente em biossólidos. Sua disponibilidade em solos que receberam o resíduo deve seguir a dinâmica da degradação da fração orgânica do biossólido, de forma semelhante ao que ocorre com o nitrogênio.

Diversas dúvidas ainda permanecem sobre o tipo de material orgânico presente no biossólido e sua capacidade de fornecer nutrientes às plantas. Também não é claro o efeito da fração orgânica do biossólido sobre a capacidade de troca catiônica (CTC) dos solos, isso porque o aumento do valor $\mathrm{pH}$ verificado em solos ratados com biossólido pode mascarar o efeito real do conteúdo orgânico na CTC e até na disponibilidade de nutrientes as plantas. 


\subsection{Uso de biossólidos em florestas}

Muitos trabalhos tem mostrado os benefícios do uso de biossólidos em áreas agrícolas (Bettiol, 1982; Berton et al., 1989; Marques, 1990; Da Ros et al, 1993 e Silva, 1995), mas trabalhos nacionais em florestas são escassos.

De acordo com Henry et al. (1994), muitas florestas tem a produtividade limitada por baixos níveis de $\mathrm{N}$ e $\mathrm{P}$ no solo. Diante disso a aplicação de biossólido de estações de tratamento de esgotos municipais pode melhorar muito a produtividade das florestas (Santos et al., 1997). Em 1994, a cidade australiana de Sydney gerou $153.000 \mathrm{Mg}$ de biossólido, sendo que aproximadamente $9 \%$ foram aplicados em áreas florestais (Polglase \& Mayers, 1995).

Estudos conduzidos na Universidade de Washington, sobre o uso do biossólido como fertilizante para silvicultura, revelaram aumentos de altura e acréscimos de diâmetro bastante expressivos em comparação com plantas controle (U.S.E.P.A., 1984).

McNab \& Berry (1985) compararam a fertilização inorgânica (896 kg ha-1 da fórmula 10-10-10 + 1,4 $\left.\mathrm{kg} \mathrm{ha}^{-1} \mathrm{de} \mathrm{CaO}\right)$ e fertilização com biossólido $\left(34 \mathrm{Mg} \mathrm{ha}^{-1}\right)$ em 3 espécies de pinus: Pinus taeda, Pinus echinata e Pinus virginiana. Os autores observaram, após 5 anos de crescimento, aumentos na produção de biomassa para as três espécies quando receberam biossólido; entretanto, a espécie Pinus virginiana foi a que melhor respondeu. Em termos de composição da biomassa, as 3 espécies fertilizadas com biossólido produziram $8 \%$ (em massa) a mais de madeira e menores quantidades de folhas que as plantas que receberam fertilizantes inorgânicos.

Prescott et al. (1993) estudaram a decomposição e taxas de entrada de materiais orgânicos em plantação de Pseudotsuga menziesii com 70 anos de idade. Para tanto, foram comparados três tratamentos: aplicação de $142 \mathrm{Mg}$ ha $^{-1}$ base seca de biossólido; fertilização inorgânica com $1082 \mathrm{~kg} \mathrm{ha}^{-1}$ de $\mathrm{N}$ e; fertilização inorgânica com $1568 \mathrm{~kg} \mathrm{ha}^{-1} \mathrm{de} \mathrm{N}$. As avaliações foram realizadas cerca de 10 anos após a aplicação dos materiais. As quantidades de $\mathrm{N}$ retomadas para o solo pela decomposição da serrapilheira, no período de um ano, não foram diferentes entre os tratamentos, assim como também não diferiram quanto ao fornecimento de $\mathrm{N}$ as plantas pela decomposição 
da serrapilheira. Para o fornecimento de $\mathrm{P}$, quantidades maiores foram fornecidas na área que recebeu biossólido.

Weetman et al. (1993) compararam para três espécies florestais do gênero Tsuga com 8 anos o uso de biossólido na dose de $17 \mathrm{Mg} \mathrm{ha}^{-1}$ e fertilização inorgânica (225 kg ha ${ }^{-1}$ de $\mathrm{N}$ e $75 \mathrm{~kg} \mathrm{ha}^{-1}$ de P). Após uma época de crescimento todas as espécies apresentaram ganhos de crescimento semelhantes, tanto as que receberam biossólido quanto as que receberam $\mathrm{N}$ e $\mathrm{P}$ inorgânicos. No entanto, os teores foliares de $\mathrm{N}$ nas plantas fertilizadas com adubo inorgânico foram superiores as que receberam biossólido.

Pesquisas realizadas pela State Forests na Austrália demonstraram que aplicações de $30 \mathrm{Mg} \mathrm{ha}^{-1}$ base seca de biossólido aumentaram o diâmetro de plantas de Pinus radiata em 28\% (Kanak et al. citados por Polglase \& Mayers, 1995).

Labrecque et al. (1995) testaram o efeito de seis doses $(0 ; 2,4 ; 4,8 ; 7,2 ; 9,6 \mathrm{e}$ $\left.12 \mathrm{Mg} \mathrm{ha}^{-1}\right)$ de biossólido seco e peletizado como fertilizante para duas espécies florestais do gênero Salix (Salix discolor Mühl e Salix viminalis L.) plantadas em solo arenoso contido em vasos de polietileno e conduzidas durante 20 semanas. $\mathrm{O}$ biossólido usado apresentava teores totais de 18,6, 8,3 e 1,4 $\mathrm{g} \mathrm{kg}^{-1}$ (base seca), para N, P e K, respectivamente. Os autores observaram que a dose $12 \mathrm{Mg} \mathrm{ha}^{-1}$ resultou em substancial aumento da biomassa das plantas fertilizadas, superando as plantas que não receberam biossólido em 5 a 7 vezes.

Phillips et al. (1996) encontraram respostas positivas em termos de crescimento para Pinus eldarica que receberam $67 \mathrm{Mg} \mathrm{ha}^{-1}$ de biossólido, sendo a biomassa produzida superior ao tratamento que recebeu adubação inorgânica com $84 \mathrm{~kg} \mathrm{ha}^{-1}$ de sulfato de amônio.

Santos et al. (1997), relatando trabalhos desenvolvidos nos Estados Unidos, citaram ganhos médios em altura de $72 \%$ (solos de baixa fertilidade), $14 \%$ (solos fertilidade média) e $12 \%$ (solos com boa fertilidade) foram registrados para três espécies arbóreas plantadas em solos que receberam $47 \mathrm{Mg} \mathrm{ha}^{-1}$ de biossólido (base seca) no plantio e avaliadas após 10 anos de crescimento. Florestas mais antigas mostraram o mesmo tipo de resposta, tendo sido empregada a mesma dose de biossólido em 
plantações com 65 anos de idade, observando-se, ao final de 6 anos, ganhos em crescimento de $65 \%$ no solo de baixa fertilidade e $40 \%$ no de alta fertilidade.

De modo geral, a maior parte das pesquisas sobre uso de biossólidos em florestas foram desenvolvidas em regiões de clima temperado, onde as condições edafoclimáticas, espécies estudadas e dinâmica das florestas diferem das encontradas em regiões de clima tropical. Tendo em vista a potencialidade do uso do biossólido em plantios florestais no Estado de São Paulo (300.000 ha segundo a ANFPC, 1985) tornase imprescindível a realização de estudos regionais com espécies de rápido crescimento, de modo a viabilizar doses adequadas para cada espécie de interesse e, gerar dados para uma avaliação econômica desse resíduo.

\subsection{Metais pesados em biossólidos, fitodisponibilidade e lixiviação no solo}

$\mathrm{O}$ termo metais pesados se refere aos elementos químicos que tem densidade maior que $5,0 \mathrm{~g} \mathrm{~cm}^{-3}$ sendo que os metais considerados micronutrientes são também classificados como metais pesados, aos quais se somam também cádmio $(\mathrm{Cd})$, níquel $(\mathrm{Ni})$, chumbo $(\mathrm{Pb})$, titânio $(\mathrm{Ti})$, estrôncio $(\mathrm{Sn})$, mercúrio $(\mathrm{Hg})$ e outros elementos de transição da tabela periódica (Mattiazzo-Prezotto, 1992). Muitas vezes usado como sinônimo, o termo "elementos traços" se refere aqueles elementos que ocorrem em níveis extremamente baixos, de poucas partes por milhão, em um sistema. Apesar dos metais pesados estarem incluídos na classificação de elementos traços, por serem encontrados em baixas concentrações na natureza, esses termos não devem ser usados como sinônimos porque os elementos traços englobam semi-metais e até não metais.

Alguns metais pesados são essenciais a plantas, animais e ao homem, tais como zinco $(\mathrm{Zn})$ e cobre $(\mathrm{Cu})$; entretanto, se ingeridos em quantidades elevadas esses elementos apresentam alta toxicidade, colocando em risco a saúde humana e animal.

Segundo Sommers \& Giordano (1984), a aplicação de biossólido a solos pode ser restringida pela presença de patógenos, sais solúveis, metais pesados e compostos orgânicos persistentes. As concentrações de metais pesados no biossólido são variáveis 
principalmente em função da origem das águas residuais. Biossólidos provenientes do tratamento dos esgotos de comunidades residenciais possuem menores teores de metais pesados comparativamente a biossólidos de origem industrial.

Os elementos $\mathrm{Cu}, \mathrm{Zn}, \mathrm{Pb}, \mathrm{Hg}, \mathrm{Cd}, \mathrm{Ni}$, molibdênio (Mo) e boro (B) são normalmente encontrados nos biossólidos em concentrações substancialmente maiores que as naturalmente encontradas em solos (Tabela 2), o que sugere que aplicações contínuas do resíduo aumentariam as concentrações dos mesmos nos solos (Purves, 1985).

Tabela 2 Teores totais de alguns elementos traços encontrados em biossólidos e solos não contaminados.

\begin{tabular}{ccccccccccc}
\hline & $\mathrm{Cu}$ & $\mathrm{Zn}$ & $\mathrm{Ni}$ & $\mathrm{Cd}$ & $\mathrm{Mo}$ & $\mathrm{Pb}$ & $\mathrm{Cr}$ & $\mathrm{B}$ \\
\hline \multirow{3}{*}{ Biossólidos } & Média & 970 & 4100 & 510 & 200 & 7 & 820 & 980 & 70 \\
& Faixa & $20-8000$ & $700-49000$ & $20-5300$ & $60-1500$ & $2-30$ & $120-3000$ & $40-8800$ & $15-1000$ \\
\multirow{6}{*}{ Solos } & & & & & & & & & & \\
& Média & 20 & 80 & 50 & 0,1 & 1 & 30 & 100 & 10 \\
& Faixa & $2-100$ & $100-300$ & $5-500$ & $0,01-0,7$ & $1-5$ & $2-200$ & $5-1000$ & $2-100$ \\
\hline
\end{tabular}

Adaptado de Purves (1985)

Os elementos arsênio (As), crômio ( $\mathrm{Cr}$ ), $\mathrm{Pb}$ e $\mathrm{Hg}$ embora de toxidez ảguda para todos sistemas biológicos, sob condições químicas normais, estão presentes nos solos sob formas inertes e não afetam o crescimento das plantas. Já $\mathrm{Cu}, \mathrm{Ni}$ e $\mathrm{Zn}$ podem ser fitotóxicos, especialmente em solos ácidos, se suas concentrações excederem os níveis críticos (Logan \& Chaney, 1983).

O principal metal pesado limitante quanto ao uso agrícola do biossólido é o $\mathrm{Cd}$. Nos Estados Unidos e em outras partes do mundo tem-se mostrado que aplicações de Cd via biossólido a solos agricultáveis aumentaram as concentrações desse elemento nos tecidos vegetais (EPA, 1983). Um fator que diferencia o $\mathrm{Cd}$ dos demais metais pesados encontrados no biossólido em níveis preocupantes é o fato de que plantas podem 
absorver quantidades relativamente elevadas desse elemento, que em função de não possuir efeito fitotóxico, pode ser transferido à cadeia alimentar (Kross et al., 1995).

Labrecque et al. (1995) encontraram para duas espécies florestais do gênero Salix fertilizadas com biossólido a seguinte ordem de transferência de alguns metais pesados do solo para as plantas: $\mathrm{Cd}>\mathrm{Zn}>\mathrm{Ni}>\mathrm{Cu}$. Outra constatação importante foi que do total de metais pesados determinados nas plantas, $58 \%$ estavam contidos nas raízes.

Kross et al. (1995) apresentaram valores máximos de alguns metais no tecido vegetal, acima dos quais há prejuízo a espécies florestais: $\mathrm{Cd}=10 \mathrm{mg} \mathrm{kg}^{-1} ; \mathrm{Cr}=8$ $\mathrm{mg} \mathrm{kg}{ }^{-1} ; \mathrm{Ni}=11 \mathrm{mg} \mathrm{kg}^{-1} ; \mathrm{Pb}=35 \mathrm{mg} \mathrm{kg}^{-1} ; \mathrm{Cu}=20 \mathrm{mg} \mathrm{kg}^{-1}$ e $\mathrm{Zn}=200 \mathrm{mg} \mathrm{kg}^{-1}$ (base seca).

Quando os metais pesados encontram-se em formas disponíveis no solo e não são absorvidos pelas plantas, estes ficam passiveis de serem lixiviados. $\mathrm{O} \mathrm{pH}$ do solo é um importante fator controlador da mobilidade desses metais e, essa mobilidade relativa de acordo com o pH foi sumarizado por Fuller, citado por Adriano (1986): em solos ácidos (pH 4,2 a 6,6), $\mathrm{Cd}, \mathrm{Hg}, \mathrm{Ni}$ e $\mathrm{Zn}$ são relativamente móveis; As e $\mathrm{Cr}$ são moderadamente móveis; e $\mathrm{Cu}$ e $\mathrm{Pb}$ são pouco móveis. Em solos neutros a alcalinos (pH 6,7 a 7,8), As e $\mathrm{Cr}$ são relativamente móveis; $\mathrm{Cd}, \mathrm{Hg}$ e $\mathrm{Zn}$ são moderadamente móveis; e $\mathrm{Cu}, \mathrm{Pb}$ e $\mathrm{Ni}$ são pouco móveis.

A matéria orgânica é outro fator que atua na disponibilidade e lixiviação de metais no solo. Conforme Hughes (1981), a M.O. pode imobilizar metais que formam complexos com materiais húmicos, tendo menor efeito quando os complexos formados tem baixa estabilidade, o que ocorre para $\mathrm{Cd}$ e $\mathrm{Zn}$ por exemplo. $\mathrm{O} \mathrm{Cu}$ é fortemente retido pela M.O., tendendo a se acumular na serrapilheira acima da superfície do solo ou nas camadas superficiais do mesmo (Melo et al, 1997).

Bertoncini \& Mattiazzo (1999) estudaram, em tubos de percolação de $25 \mathrm{~cm}$ de altura, a lixiviação de alguns metais pesados aplicados via biossólido a três solos de diferentes texturas e teores de óxidos de ferro e alumínio. Os teores de $\mathrm{Cd}, \mathrm{Cr}, \mathrm{Cu}, \mathrm{Ni}$ e $\mathrm{Zn}$ adicionados aos solos foram 1,7, 27,3 , 48,9, 22,0 e $155 \mathrm{mg} \mathrm{kg}^{-1}$, respectivamente. Os autores observaram após 310 dias de incubação que a retenção de $\mathrm{Cd}, \mathrm{Cr}, \mathrm{Cu}$ e $\mathrm{Ni}$ foi maior quanto maior o teor de óxidos de ferro no solo. Além disso, o aumento do $\mathrm{pH}$ e 
matéria orgânica provocada pela adição de biossólido, contribuíram para menor mobilidade dos metais estudados.

Anjos (1999) não constatou lixiviação dos metais $\mathrm{Cd}, \mathrm{Cr}, \mathrm{Cu}, \mathrm{Mn}, \mathrm{Ni}, \mathrm{Pb}$ e $\mathrm{Zn}$ para camadas de terra inferiores a $60 \mathrm{~cm}$ de profundidade em dois Latossolos distróficos que receberam repetidas aplicações de biossólido, num total de $388 \mathrm{Mg} \mathrm{ha}^{-1}$. O autor atribuiu tal comportamento a interação entre os fatores: elevação do $\mathrm{pH}$ do solo, presença de ligantes e Ca fornecido pelo biossólido e presença de óxidos de ferro e alumínio.

Shuman (1999) estudou o efeito da adição de diferentes materiais orgânicos, dentre eles biossólido, sobre a adsorção de $\mathrm{Zn}$ em dois solos, um de textura arenosa e outro de textura argilosa. Os resíduos orgânicos aplicados aumentaram a adsorção de $\mathrm{Zn}$ nos tratamentos em solo arenoso, mas o mesmo não ocorreu para o solo argiloso, onde houve aumento da energia de ligação do $\mathrm{Zn}$ no solo, ao invés de aumento na adsorção. Diante destas constatações o autor concluiu que o biossólido pode ser usado como remediador em solos contaminados com elevados teores de $\mathrm{Zn}$ e, o efeito seria mais evidente em solos com maiores teores de areia.

Zhu \& Alva (1993) estudaram o efeito dos cátions $\mathrm{Ca}^{+2}, \mathrm{Mg}^{+2}$ e $\mathrm{K}^{+}$adicionados via sais (sulfatos) na lixiviação de $\mathrm{Cu}$ e $\mathrm{Zn}$ num solo arenoso $(\mathrm{pH}=7,35)$, usando colunas de lixiviação de $28 \mathrm{~cm}$. A análise do lixiviado revelou teores maiores de $\mathrm{Cu}$ e $\mathrm{Zn}$ nos tratamentos que receberam $\mathrm{K}_{2} \mathrm{SO}_{4}$, além de teores mais elevados de carbono orgânico dissolvido (C.O.D.), o que foi indicativo de complexação desses metais com ligantes orgânicos na solução do solo. $\mathrm{O} \mathrm{CaSO}_{4}$ foi o material que provocou menor recuperação de $\mathrm{Cu}$ e $\mathrm{Zn}$ no lixiviado, assim como menores concentrações de C.O.D. O autor concluiu que a aplicação de $\mathrm{K}^{+}$via sais inorgânicos pode incrementar a lixiviação de $\mathrm{Cu}$ e $\mathrm{Zn}$. Esses resultados concordam com os encontrados por Bertoncini \& Mattiazzo (1999).

A disponibilidade e lixiviação de metais pesados no solo é dependente de alguns fatores inerentes ao solo e ao próprio biossólido, assim como aspectos ligados ao clima. A aplicação de biossólido por longos períodos numa mesma área deve ser rigorosamente monitorada, pois ainda permanece indefinido a capacidade dos solos em 
"reter" esses metais e, a influência do próprio biossólido sobre essa capacidade. Desse modo alterações mais drásticas no sistema solo, como por exemplo mudança no $\mathrm{pH}$, podem ter efeito sobre a disponibilização dos metais, o que é motivo de preocupação quanto ao futuro dessa área.

\subsection{Aspectos da legislação ligados a metais pesados no biossólido}

Devido aos problemas de toxidez associados aos metais pesados, muitos países possuem leis específicas para disciplinar o uso agroflorestal dos biossólidos. Nos Estados Unidos a Environmental Protection Agency (EPA) determina as quantidades máximas de metais pesados que podem estar presentes no biossólido e, em função desses teores podem ser calculadas doses e freqüência de aplicação do material (EPA, 1993) (Tabela 3). As normas da EPA serviram como base para a elaboração dos critérios de uso agrícola para biossólidos no Estado de São Paulo (CETESB, 1999).

Tabela 3 Limites estabelecidos pela EPA disciplinando o uso de biossólido na agricultura.

\begin{tabular}{cccc}
\hline Elemento & $\begin{array}{c}\text { Concentração máxima } \\
\text { no biossólido }\end{array}$ & $\begin{array}{c}\text { Dose máxima de } \\
\text { aplicação anual }\end{array}$ & $\begin{array}{c}\text { Dose máxima de aplicação } \\
\text { acumulada }\end{array}$ \\
\hline $\mathrm{mg} \mathrm{kg}{ }^{-1}$ & 75 & $\mathrm{~kg} \mathrm{ha}^{-1}$ ano $^{-1}$ & $\mathrm{~kg} \mathrm{ha}^{-1}$ \\
$\mathrm{Cd}$ & 85 & 2 & 41 \\
$\mathrm{Cr}$ & 3000 & 1,9 & 39 \\
$\mathrm{Cu}$ & 4300 & 150 & 3000 \\
$\mathrm{~Pb}$ & 840 & 75 & 1500 \\
$\mathrm{Hg}$ & 57 & 15 & 300 \\
$\mathrm{Mo}$ & 75 & 0,85 & 17 \\
$\mathrm{Ni}$ & 420 & 0,90 & 18 \\
$\mathrm{Se}$ & 100 & 21 & 420 \\
$\mathrm{Zn}$ & 7500 & 5 & 100 \\
\hline
\end{tabular}


Esses limites tem sido questionados para algumas regiões dos EUA que possuem solos mais ácidos, onde haveria a possibilidade dos metais pesados estarem mais fitodisponíveis e sujeitos a lixiviação (Chang et al., 1987). Situação semelhante é comum à maioria dos solos brasileiros.

A adoção dos parâmetros da EPA para o uso agrícola do biossólido no Brasil é uma saída que deve ser enxergada como provisória, pois embora os estudos para a elaboração da lei norte-americana tenham sido intensos, sua aplicação em nossas condições pode ser desastrosa a longo prazo, uma vez que as condições edafoclimáticas do Brasil pouco se assemelham a maior parte dos EUA.

\subsection{Taxa de mineralização do nitrogênio do biossólido e lixiviação de nitrato.}

Nitrogênio na forma de nitrato é fonte essencial de $\mathrm{N}$ para as plantas, mas é também considerado poluente potencial pela EPA (Gaines \& Gaines, 1994).

A dose de biossólido a ser aplicada a solos agrícolas ou florestais pode ser calculada em função da capacidade do biossólido em suprir parcial ou totalmente a necessidade de $\mathrm{N}$ por determinada cultura durante seu ciclo. Se a dose for excessiva e a taxa de mineralização do $\mathrm{N}$ orgânico do resíduo permitir, pode haver movimentação de nitrato no perfil vertical do solo e contaminação do lençol freático (Glória, 1992). Doses elevadas de biossólido além de estarem associadas a contaminação de águas superficiais e subterrâneas por nitrato, podem proporcionar lixiviação de alguns cátions nutrientes ( $\mathrm{Ca}$ e $\mathrm{Mg}$ ) e metais pesados (Cd) para camadas mais profundas do solo (Medalie et al., 1994).

Nos EUA a EPA, em levantamento nacional realizado, estimou que cerca de $2,4 \%$ da água consumida em áreas rurais excede o limite máximo para $\mathrm{NO}_{3}^{-}$em água potável que é de $10 \mathrm{mg} \mathrm{L}^{-1}$ (Kross et al., 1995).

Epstein et al. (1978) estudaram a mineralização do $\mathrm{N}$ orgânico em lodo de esgoto digerido ( $\mathrm{N}$-total $=28,9 \mathrm{~g} \mathrm{~kg}^{-1}$; relação $\mathrm{C} / \mathrm{N}=8$ ) e lodo de esgoto compostado $\left(\mathrm{N}\right.$-total $=9,9 \mathrm{~g} \mathrm{~kg}^{-1}$; relação $\left.\mathrm{C} / \mathrm{N}=18\right)$, aplicados a um solo argiloso contido em tubos 
de percolação em doses correspondentes a $0,454,907$ e $1814 \mathrm{~kg} \mathrm{ha}^{-1}$ de $\mathrm{N} \mathrm{e}$, incubados à $35^{\circ} \mathrm{C}$ durante 15 semanas. Os resultados obtidos permitiram observar que o comportamento inicial da mineralização líquida foi diferente entre os biossólidos, sendo que o lodo compostado liberou menores quantidades de N. O diferente valor da relação $\mathrm{C} / \mathrm{N}$ dos lodos é fator a ser considerado na avaliação da mineralização do $\mathrm{N}$ de biossólidos.

Lindemann \& Cardenas (1984) estudaram a mineralização do N-orgânico adicionado via biossólido ( $\mathrm{N}$-total $=22,3 \mathrm{~g} \mathrm{~kg}^{-1}$; $\mathrm{N}$-inorgânico $=2,1 \mathrm{mg} \mathrm{kg}^{-1}$ e relação $\mathrm{C} / \mathrm{N} \mathrm{4,3)}$ nas doses 0,15 e $30 \mathrm{~g} \mathrm{~kg}^{-1}$ à dois solos com características texturais diferentes: um arenoso e outro argiloso. Ao final de 32 semanas de incubação os autores não observaram correlação entre o $\mathrm{N}$ potencialmente mineralizável $\left(\mathrm{N}_{0}\right)$ e a constante de velocidade da reação de mineralização (k) (Tabela 4). Em outro estudo Linderman et al. (1988) encontraram correlação negativa entre o $\mathrm{N}_{0}$ e $\mathrm{k}$, ou seja quanto maior o $\mathrm{N}_{0}$, menor é o valor de $\mathrm{k}$, sugerindo que em função da dose de biossólido aplicada pode haver redução da mineralização do $\mathrm{N}$.

Tabela 4 Estimativa do $\mathrm{N}$ potencialmente mineralizável $\left(\mathrm{N}_{0}\right)$ e constante de velocidade da reação de mineralização $(k)$ em dois solos que receberam doses de biossólido.

\begin{tabular}{cccc}
\hline Solo & Biossólido & $\mathrm{N}_{0}$ & $\mathrm{k}$ \\
\hline \multirow{2}{*}{ Arenoso } & $\mathrm{g} \mathrm{kg}^{-1}$ & $\mathrm{mg} \mathrm{kg}^{-1}$ & Semana $^{-1}$ \\
& 0 & 64,6 & 0,030 \\
& 15 & 155,6 & 0,058 \\
& 30 & 237,7 & 0,041 \\
Argiloso & 0 & & 0,051 \\
& 15 & 73,4 & 0,038 \\
& 30 & 181,9 & 0,048 \\
\hline
\end{tabular}

Adaptado de Lindemann \& Cardenas (1984). 
Segundo Hart et al. (1988) a dose máxima aceitável de biossólido varia com o tipo de biossólido, pois cada um se encontra num estágio particular de decomposição e, por isso, as taxas de mineralização do nitrogênio (TMN) são diferentes (Tabela 5). Para solos ácidos florestais, Burton et al. (1990) destacaram, tipo de biossólido, tipo de floresta e histórico de aplicações anteriores, como fatores que influenciam a nitrificação e o potencial de lixiviação de $\mathrm{NO}_{3}$.

Tabela 5 Nitrogênio disponível após um ano de aplicação no solo. Resultados expressos em kg de $\mathrm{N}$ por Mg de biossólido, base seca.

\begin{tabular}{|c|c|c|}
\hline Tipo de biossólido & Líquido & Prensado \\
\hline & & - \\
\hline Não digerido & $22,7-36,3$ & $9,1-18,2$ \\
\hline Digerido aerobicamente & $13,6-27,2$ & $7,3-13,6$ \\
\hline Digerido anaerobicamente & $13,6-27,2$ & $4,5-9,1$ \\
\hline Compostado & - & $0,9-4,5$ \\
\hline
\end{tabular}

Adaptado de Hart et al. (1988).

$\mathrm{O}$ efeito do tipo de biossólido sobre a TMN tem sido observado por diversos autores, entre eles Serna \& Pomares (1992), Cox (1995) e Shepherd (1996).

Misselbrook et al. (1996) aplicaram $140 \mathrm{~m}^{3} \mathrm{ha}^{-1}\left(=802 \mathrm{~kg} \mathrm{ha}^{-1}\right.$ de N) de lodo líquido bruto injetado no solo, e $125 \mathrm{~m}^{3} \mathrm{ha}^{-1}$ de lodo líquido digerido anaeróbio injetado no solo ou aplicado superficialmente entre os anos de 1991 e 1993. A concentração de $\mathrm{NO}_{3}{ }^{-}$na solução do solo a $90 \mathrm{~cm}$ de profundidade excedeu o limite permitido para água potável da Comunidade Européia $\left(11,3 \mathrm{mg} \mathrm{L}^{-1}\right)$ pelo menos duas vezes durante o período de estudo para o lodo digerido anaeróbio injetado no solo. Calcula-se que cerca de 24,11 e $6 \%$ do $\mathrm{N}$ aplicado via lodo foi lixiviado para camadas do solo abaixo de $90 \mathrm{~cm}$, para lodo digerido anaeróbio injetado, lodo digerido anaeróbio aplicado superficialmente e lodo bruto injetado, respectivamente.

Artiola (1991) estudou a lixiviação de nitrato em três solos com texturas diferentes sob plantio de algodão, onde foi aplicado lodo de esgoto líquido via irrigação em sulcos. Os tratamentos foram: 1- Controle (não fertilizado); 2- $180 \mathrm{~kg} \mathrm{ha}^{-1}$ de $\mathrm{N}$ via 
lodo de esgoto; 3- $180 \mathrm{~kg} \mathrm{ha}^{-1}$ de $\mathrm{N}$ via fosfato de amônio e uréia; 4- $540 \mathrm{~kg} \mathrm{ha}^{-1}$ de $\mathrm{N}$ via lodo de esgoto. As concentrações de $\mathrm{NO}_{3}{ }^{-}$nas camadas de 0-150 cm para os três solos obedeceram a seguinte ordem: tratamento $4>>$ tratamento $2 \geq$ tratamento $3>>$ tratamento 1. O autor destacou que as características texturais do solo e variações no fornecimento de água, podem ser muitas vezes mais determinantes sobre os teores de $\mathrm{NO}_{3}{ }^{-}$e outros solutos presentes na zona de absorção radicular, que os tratamentos com $\mathrm{N}$.

Cox (1995) comparou diferentes fontes de $\mathrm{N}$ para duas espécies (Tagetes erecta L. e Impatiens sp. hybrids) crescendo durante 50 dias em vasos contendo substrato comercial. As espécies foram escolhidas pela importância comercial das mesmas e, por diferirem no padrão de crescimento e absorção de $\mathrm{N}$. As fontes de $\mathrm{N}$ foram: fertilizante inorgânico altamente solúvel; fertilizante inorgânico de liberação controlada; biossólido proveniente de tratamento primário e; biossólido de tratamento secundário. Os tratamentos foram realizados de modo a aplicar quantidades iguais de $\mathrm{N}$, $450 \mathrm{mg}$ vaso $^{-1}$, para Targetes erecta e, $400 \mathrm{mg} \mathrm{vaso}^{-1}$ para Impatiens sp., independente da fonte usada. As fontes de $\mathrm{N}$ foram aplicadas sozinhas e, tratamentos adicionais com a combinação entre os dois biossólidos e os dois fertilizantes inorgânicos também foram testados. A lixiviação de formas nitrogenadas foi avaliada pela coleta de lixiviado de 10 em 10 dias durante o período do experimento. A análise dos dados revelou que os biossólidos aplicados sozinhos não são capazes de suprir adequadamente as plantas de Targetes erecta com N, embora menores concentrações de $\mathrm{N}$ nos lixiviados tenham sido encontrados nesses tratamentos, se comparado aos fertilizantes inorgânicos aplicados sozinhos. Para a outra espécie, os biossólidos aplicados sozinhos proporcionaram produções de matéria seca iguais às conseguidas com os fertilizantes inorgânicos aplicados sozinhos e, como no caso anterior, menores quantidades de $\mathrm{N}$ foram lixiviadas. As combinações dos biossólidos + fertilizantes inorgânicos para Targetes erectus resultaram nas menores quantidades de $\mathrm{N}$ lixiviado dentre as fontes testadas e, para Impatiens sp. o inverso ocorreu. O autor concluiu então que os biossólidos podem fornecer, de forma segura, adequadas quantidades de $\mathrm{N}$ para plantas de crescimento lento e baixa taxa de absorção de N (Impatiens sp.), entretanto para plantas de rápido 
crescimento e elevadas taxas de absorção de $\mathrm{N}$, os biossólidos devem ser combinados com fertilizantes solúveis.

Henry et al. (1994), em experimento onde foram avaliadas diferentes condições da floresta e sua relação com a lixiviação de $\mathrm{N}$ aplicado via biossólido, concluíram que clareiras e florestas maduras são mais susceptíveis à lixiviação de $\mathrm{N}$ do que florestas jovens, isso porque as espécies vegetais em florestas jovens, por estar em rápido crescimento, absorvem maiores quantidades de nitrogênio da solução do solo, reduzindo por conseqüência as quantidades de $\mathrm{N}$ passíveis de lixiviação. Ainda segundo os mesmos autores, grande parte do $\mathrm{N}$ lixiviado ocorre no primeiro ano, cai rapidamente no segundo ano e, no terceiro ano após aplicação do biossólido, a água já atende o limite estabelecido pela EPA para concentração de nitratos. As quantidades de $\mathrm{N}$ lixiviadas no primeiro ano após aplicação do biossólido aparecem na Tabela 6 .

Tabela 6 Lixiviação de $\mathrm{N}$ no primeiro ano após aplicação de $47 \mathrm{Mg} \mathrm{ha}^{-1}$ (base seca) de biossólido em clareira e florestas em diferentes estágios de desenvolvimento.

\begin{tabular}{cc}
\hline Tratamento & Lixiviação aos $50 \mathrm{~cm}$ de profundidade \\
\hline Clareira & $\mathrm{kg} \mathrm{ha}^{-1}$ \\
Floresta madura & 115 \\
Floresta jovem & 479 \\
Testemunha & 73 \\
\hline
\end{tabular}

Adaptado de Henry et al. (1994).

Artiola \& Pepper (1992) avaliaram o impacto de 5 aplicações anuais de lodo de esgoto líquido sobre os conteúdos de carbono (C) e $\mathrm{N}$ de um solo. Do total de M.O. adicionada via lodo, $65 \%$ foi mineralizada em um ano, aumentando as formas solúveis de C-orgânico e $\mathrm{N}$ do solo, mas não alterando os teores totais dos dois elementos no solo. Os resultados de Artiola \& Pepper (1992) não concordam com Raison et al. (1992), pois estes últimos não verificaram alterações na mineralização do nitrogênio com a aplicação de 13,3 $\mathrm{Mg} \mathrm{ha}^{-1}$ ano $^{-1}$ durante 4 anos. 
Medalie et al. (1994) estudaram a lixiviação de alguns cátions e ânions em um solos florestal, com e sem vegetação, que recebeu biossólido $\left(60 \mathrm{~g} \mathrm{~kg}^{-1}\right.$ de $\left.\mathrm{N}\right)$ nas doses: $0,3,3,6,9$ e 14,5 $\mathrm{Mg} \mathrm{ha}^{-1}$; para tanto, coletas de amostras da solução do solo abaixo de $60 \mathrm{~cm}$ de profundidade foram tomadas e nelas determinados os cátions e ânions de interesse. As doses de biossólido elevaram os teores de $\mathrm{NO}_{3}^{-}$nas parcelas sem vegetação, ultrapassando o limite para água potável recomendado pela EPA, porém nas áreas vegetadas, os teores em nenhum momento excederam esse limite. Os autores concluíram que a absorção de $\mathrm{N}$ pelas plantas é um importante fator no estabelecimento da dose de biossólido a ser aplicada.

Oliveira (1995) num experimento em laboratório utilizando solos (Latossolo Vermelho Escuro-LE e Areia Quartzoza-AQ) colocados em colunas de $40 \mathrm{~cm}$ de altura e tratados com biossólido na camada superficial, em quantidades correspondentes a 13,5, 27,0 e $40,0 \mathrm{Mg} \mathrm{ha}^{-1}$ base seca, quantificou o $\mathrm{N}$-inorgânico presente no líquido percolado através das colunas de terra ao final de 119 dias de incubação onde, periodicamente, se fazia a adição de água a fim de provocar lixiviação. Em função dos resultados obtidos, o autor sugere que existe a possibilidade de se perder até $47,5 \%$ do $\mathrm{N}$ adicionado via biossólido, para camadas abaixo de $40 \mathrm{~cm}$, sendo essas perdas muito mais evidentes no solo arenoso.

Um Latossolo Vermelho-Amarelo distrófico textura média e um Latossolo Roxo distrófico textura argilosa que receberam repetidas aplicações de biossólido (média por aplicação de $78 \mathrm{Mg} \mathrm{ha}^{-1}$ ), num total de $388 \mathrm{Mg} \mathrm{ha}^{-1}$ base seca tiveram a lixiviação de nitratos avaliada por Anjos (1999). Os resultados evidenciaram que aplicações repetidas de biossólido promoveram maiores perdas de $\mathrm{NO}_{3}{ }^{-}$para camadas abaixo de $60 \mathrm{~cm}$ de profundidade, que atingiram valores de até $96 \mathrm{mg} \mathrm{L}^{-1}{\mathrm{de} \mathrm{NO}_{3}}^{-}$nos lixiviados coletados. Apesar dos valores encontrados no lixiviado excederem o limite máximo para nitrato em água potável de $10 \mathrm{mg} \mathrm{L}^{-1}$ (EPA, 1993), as quantidades totais perdidas por lixiviação representaram apenas uma pequena parcela do total de $\mathrm{N}$ adicionado via resíduo.

A determinação da taxa de mineralização do nitrogênio é parâmetro importante no uso agrícola do biossólido, pois doses adequadas a determinada cultura podem ser 
estabelecidas, prevenindo a poluição de águas subterrâneas pela lixiviação de nitratos provenientes da mineralização do $\mathrm{N}$ do resíduo. Um inconveniente, é que os métodos para determinar a TMN são demorados ( 25 a 32 semanas) e os resultados se aplicam apenas para o biossólido avaliado e para o solo onde foi aplicado, não permitindo extrapolações. Nesse sentido a utilização de métodos químicos para determinação do Ndisponível do biossólido, por serem rápidos, tem sido testados para uma aplicação mais rotineira. Serna \& Pomares (1992) testaram 4 métodos químicos para estimar o N disponível em biossólidos: a- Método da autoclave; b- Método do permanganato de potássio em meio ácido; c- Método do $\mathrm{HCl} \mathrm{e;} \mathrm{d-} \mathrm{Método} \mathrm{da} \mathrm{pepsina.} \mathrm{Os} \mathrm{métodos} \mathrm{da}$ pepsina e do $\mathrm{HCl}$ tiveram alta correlação com o $\mathrm{N}$ absorvido por plantas crescendo sob condições controladas, sendo recomendado pelos autores para estimar o $\mathrm{N}$ disponível no biossólido. 


\section{MATERIAL E MÉTODOS}

\subsection{Localização da área experimental}

O presente trabalho foi realizado na Estação Experimental da Escola Superior de Agricultura "Luiz de Queiroz" (ESALQ / USP), localizada em Itatinga-SP (22 59' de latitude sul e $48^{\circ} 41^{\prime}$ de longitude oeste), a aproximadamente $220 \mathrm{~km}$ da cidade de São Paulo-SP.

As condições edafoclimáticas e florísticas da área experimental são representativas de extensos blocos de florestas homogêneas plantadas no planalto paulista. O clima é do tipo Cwa, segundo a classificação de Köeppen, isto é, mesotérmico de inverno seco, com temperatura média do mês mais frio (julho) inferior a $18^{\circ} \mathrm{C}$ e do mês mais quente (janeiro) superior a $22^{\circ} \mathrm{C}$. A precipitação média anual é cerca de $1300 \mathrm{~mm}$ e o total de chuvas no mês mais seco não ultrapassa $30 \mathrm{~mm}$.

\subsection{Solo}

Amostras de um Latossolo Vermelho-Amarelo distrófico de textura arenosa, foram retiradas das camadas 0-30, 30-60 e 60-90 cm, secas ao ar, peneiradas (malha de $2 \mathrm{~mm}$ ), homogeneizadas e submetidas às análises para caracterização química (Tabela 7), granulométrica e teores totais de óxidos de ferro, alumínio e silício (Tabela 8). 
Tabela 7 Caracterização química do solo utilizado no experimento.*

\begin{tabular}{|c|c|c|c|c|c|c|c|c|c|c|c|c|}
\hline Profundidade & $\overline{\mathrm{pH}}$ & M.O. & $\overline{\mathbf{P}}$ & $\mathbf{K}$ & $\overline{\mathbf{C a}}$ & $\mathbf{M g}$ & $\mathrm{H}+\mathrm{Al}$ & $\overline{A l}$ & $\overline{\text { SB }}$ & CTC & $\mathrm{V} \%$ & $\mathrm{~m} \%$ \\
\hline & $\mathrm{CaCl}_{2}$ & $\mathrm{~g} \mathrm{dm}^{-3}$ & $\mathrm{mg} \mathrm{dm^{-3 }}$ & & & & $-m \mathrm{~mm}$ & $\mathrm{l}_{\mathrm{c}} \mathrm{dn}$ & 3 & & & \\
\hline $0-30$ & 4,0 & 16 & 1 & 1,2 & 1 & 1 & 34,0 & 7 & 3 & 37 & 9 & 69 \\
\hline $30-60$ & 4,0 & 15 & 1 & 0,5 & 1 & 1 & 31,0 & 6 & 3 & 34 & 7 & 71 \\
\hline $60-90$ & 4,1 & 14 & 1 & 0,3 & 1 & 1 & 28,0 & 5 & 2 & 30 & 8 & 68 \\
\hline
\end{tabular}

*Análise segundo Raij \& Quaggio (1983)

Tabela 8 Granulometria e teores totais de óxidos de ferro, alumínio e silício.*

\begin{tabular}{cccccccc}
\hline Profundidade & Argila & Areia grossa & Areia fina & Silte & $\mathrm{Fe}_{2} \mathbf{O}_{3}$ & $\mathbf{A l}_{2} \mathbf{O}_{3}$ & $\mathbf{S i O}_{2}$ \\
\hline $0-30$ & 168 & 532 & 241 & 59 & 25,0 & 64,0 & 45,0 \\
$30-60$ & 190 & 495 & 266 & 49 & 27,4 & 64,0 & 47,0 \\
$60-90$ & 197 & 496 & 278 & 29 & 28,8 & 76,0 & 48,0 \\
\hline
\end{tabular}

* Análise segundo Camargo et al. (1986).

\subsection{Biossólido}

O biossólido usado foi proveniente da Estação de Tratamento de Esgotos (ETE) de Barueri/SABESP, Barueri-SP. Nesta estação o biossólido é resultante do tratamento dos esgotos pelo processo de lodos ativados convencionais com aeração por ar difuso e digestão anaeróbia dos lodos primários e secundários. No final do processo há adição de cloreto férrico e cal para aumentar a eficiência da prensagem que é realizada para reduzir o teor de água do biossólido. A adição de cal visa também a redução de patógenos que podem estar presentes no biossólido, sendo que o biossólido de Barueri é classificado como tipo "B" segundo critério da EPA (1993), o que significa que a concentração de coliformes fecais no resíduo é inferior a 2.000.000 NMP g ${ }^{-1}$ de sólidos totais. 
Algumas características químicas do biossólido foram determinadas no Laboratório de Química Ambiental do Departamento de Ciências Exatas da ESALQ/USP (Tabela 9).

Tabela 9 Caracterização química parcial do biossólido utilizado. Resultados expressos no material seco a $65^{\circ} \mathrm{C}$.

\begin{tabular}{lc}
\hline pH em água & 10,6 \\
Umidade $65^{\circ} \mathrm{C}\left(\mathrm{g} \mathrm{kg}^{-1}\right)$ & 615,2 \\
M.O. $\left(\mathrm{g} \mathrm{kg}^{-1}\right)$ & 264,11 \\
Carbono $\left(\mathrm{g} \mathrm{kg}^{-1}\right)$ & 165,12 \\
Nitrogênio total $\left(\mathrm{g} \mathrm{kg}^{-1}\right)$ & 15,34 \\
Nitrogênio inorgânico $\left(\mathrm{g} \mathrm{kg}^{-1}\right)$ & 1,41 \\
Relação $\mathrm{C} / \mathrm{N}$ & 10,76 \\
Fósforo $\left(\mathrm{g} \mathrm{kg}^{-1}\right)$ & 10,06 \\
Potássio $\left(\mathrm{g} \mathrm{kg}^{-1}\right)$ & 1,23 \\
Cálcio $\left(\mathrm{g} \mathrm{kg}^{-1}\right)$ & 149,95 \\
Magnésio $\left(\mathrm{g} \mathrm{kg}^{-1}\right)$ & 3,76 \\
Sódio $\left(\mathrm{g} \mathrm{kg}^{-1}\right)$ & 0,59 \\
Cádmio $\left(\mathrm{mg} \mathrm{kg}^{-1}\right)$ & 14 \\
Zinco $\left(\mathrm{mg} \mathrm{kg}^{-1}\right)$ & 1555 \\
Cobre $\left(\mathrm{mg} \mathrm{kg}^{-1}\right)$ & 394 \\
Ferro $\left(\mathrm{mg} \mathrm{kg}^{-1}\right)$ & 39763 \\
Cromo $\left(\mathrm{mg} \mathrm{kg}^{-1}\right)$ & 378 \\
Níquel $\left(\mathrm{mg} \mathrm{kg}^{-1}\right)$ & 227 \\
\hline
\end{tabular}

\subsection{Espécie florestal}

A espécie florestal escolhida foi o Eucalyptus grandis, pela importância econômica no Estado de São Paulo para a produção de celulose, papel e madeira. Essa espécie é originária da Austrália, onde se desenvolve em regiões de clima quente e úmido, sobre solos de alta fertilidade (Barros et al., 1990). No Estado de São Paulo é cultivado geralmente em solos de baixa fertilidade natural, porém mostra respostas 
significativas quando da fertilização com N, P e K (Novais et al., 1990); aspecto este também levado em consideração na escolha da espécie.

\subsection{Delineamento experimental}

A instalação das parcelas experimentais seguiu o delineamento experimental em blocos ao acaso, com 4 tratamentos em 4 blocos, num total de 16 parcelas, cada uma constituída por 100 plantas de E. grandis (10 linhas com 10 plantas cada). A área útil de cada parcela compreendeu as 36 plantas centrais, sendo as demais colocadas como bordadura dupla (Figura 1).

* Plantas da bordadura

* Plantas da área útil

$\mathrm{x}$ Pontos de coleta de solo

\section{$20 \mathrm{~m}$}

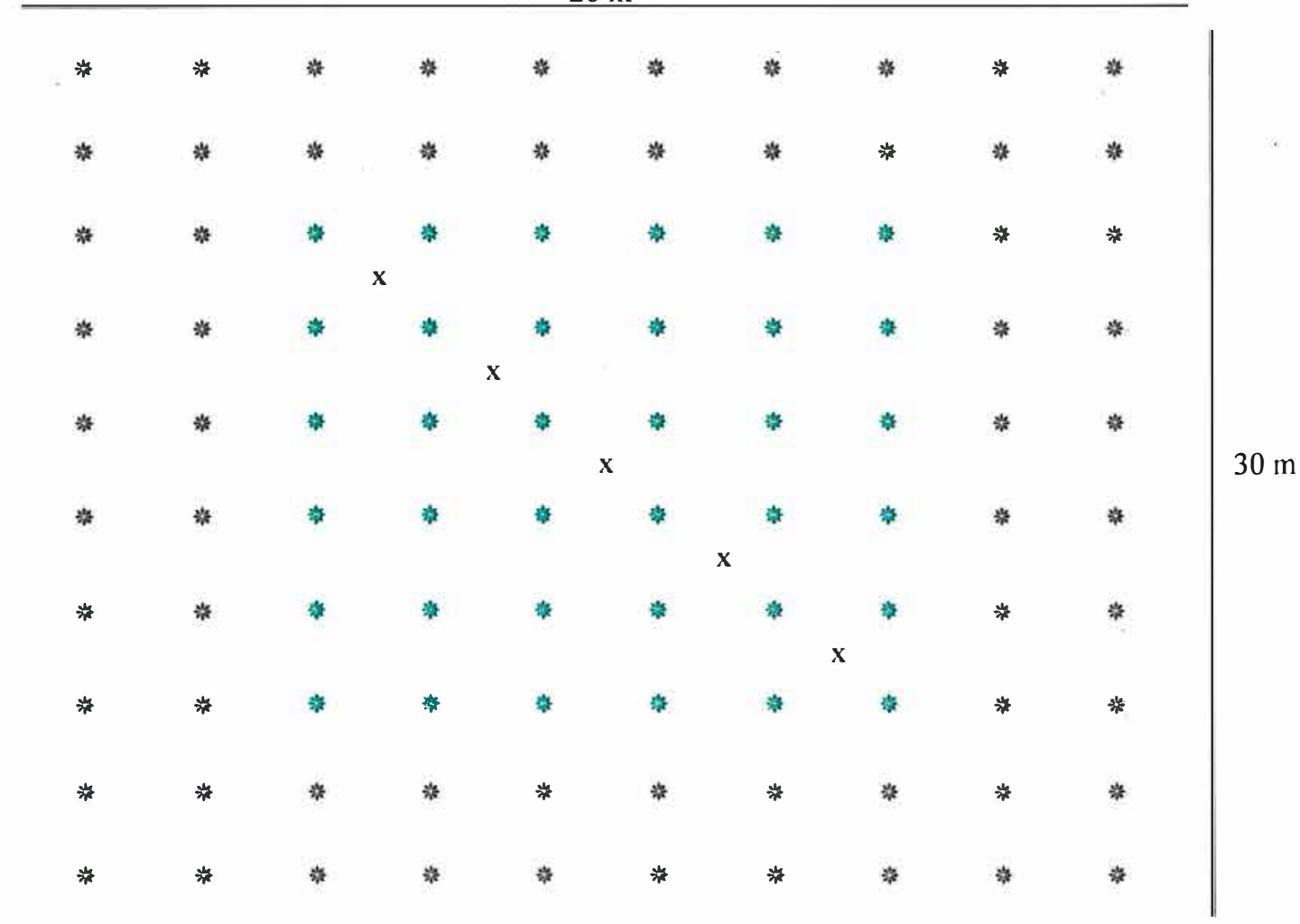

Figura 1 Esquema das parcelas experimentais, com a bordadura, área útil e pontos de coleta de solo. 


\subsection{Instalação do experimento}

$\mathrm{Na}$ área escolhida foi realizado corte raso da antiga plantação de Eucalyptus grandis (com 7 anos de idade) e implantada nova floresta no sistema de cultivo mínimo com mudas de Eucalyptus grandis propagadas via sementes. As mudas foram plantadas nas entrelinhas da antiga plantação (espaçamento 3,0 x 2,0 m), sem preparo do solo, apenas sulcação para o plantio, que foi realizado em março de 1998.

A aplicação do biossólido foi feita 4 meses após o plantio das mudas, ou seja julho de 1998. O biossólido foi aplicado, com umidade original $\left(615,2 \mathrm{~g} \mathrm{~kg}^{-1}\right)$, em faixas de $2 \mathrm{~m}$ sobre a superfĩcie do solo e nas entrelinhas da cultura, preservando uma distância de $0,5 \mathrm{~m}$ de cada lado das linhas de plantio. A aplicação foi feita com carreta de distribuição de resíduos da marca Arador, cujo sistema de distribuição é acionado por uma bomba hidráulica de baixa vazão que movimenta uma esteira localizada na base da carreta, promovendo a aplicação do resíduo. O volume da caçamba é de $2,73 \mathrm{~m}^{3}$ (Figura 2).

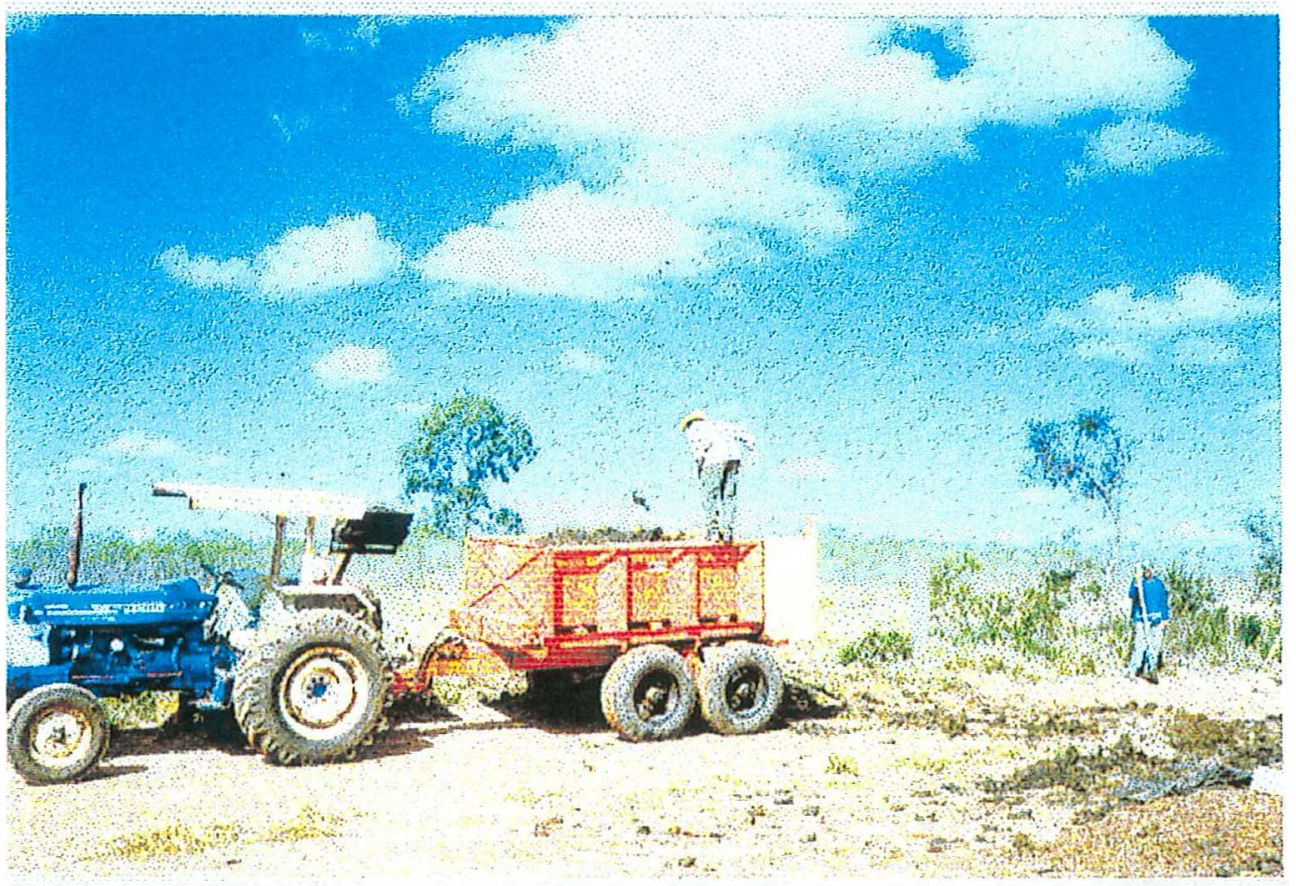

Figura 2 Carreta usada na distribuição do biossólido. 
O aspecto do biossólido aplicado sobre o solo pode ser observado na Figura 3.

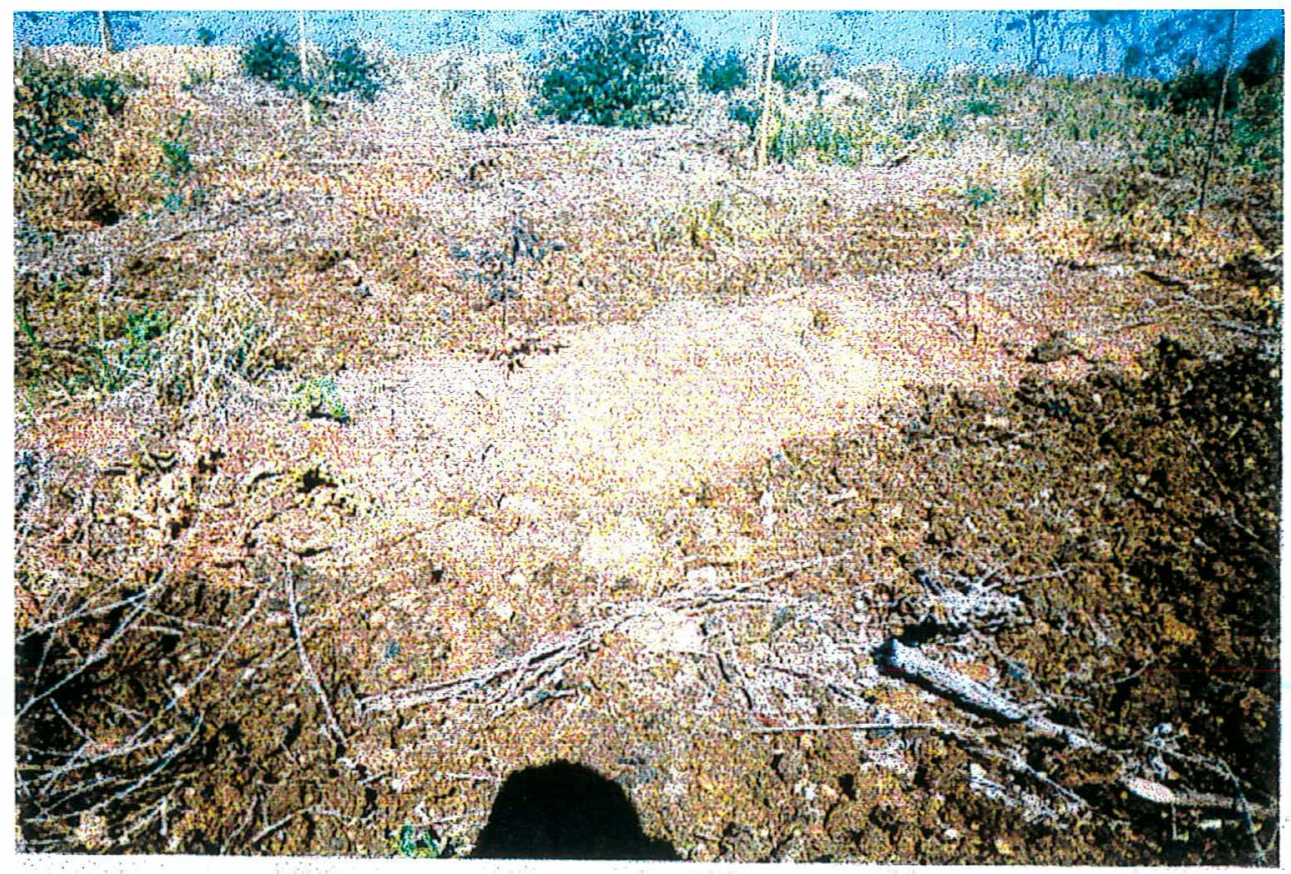

Figura 3 Parcela experimental que recebeu $40 \mathrm{Mg} \mathrm{ha}^{-1}$ de biossólido.

Os tratamentos testados foram:

1- Testemunha absoluta: sem biossólido e sem potássio;

2- $10 \mathrm{Mg} \mathrm{ha}^{-1}$ de biossólido (base seca) + suplementação potássica;

3- $\quad 20 \mathrm{Mg} \mathrm{ha}^{-1}$ de biossólido (base seca) + suplementação potássica;

4- $\quad 40 \mathrm{Mg} \mathrm{ha}^{-1}$ de biossólido (base seca) +suplementação potássica.

As suplementações potássicas foram realizadas durante o primeiro ano de crescimento, tendo em vista que o $\mathrm{K}$ do biossólido não atenderia a necessidade da cultura. No cálculo das suplementações foi considerado o $\mathrm{K}$ aplicado via biossólido, de modo que essa quantidade somada à suplementação com $\mathrm{KCl}$ deveria atingir um total de $137 \mathrm{~kg} \mathrm{ha}^{-1}$ de K. Desse modo as doses de K aplicadas foram 124, 112 e $88 \mathrm{~kg} \mathrm{ha}^{-1}$ respectivamente para os tratamentos 2,3 e 4 . A aplicação do fertilizante inorgânico foi parcelada da seguinte forma: 
Tratamento 2: $32 \mathrm{~kg} \mathrm{ha}^{-1}$ de $\mathrm{K}$ aplicado ao redor das mudas, 45 dias após plantio ; $50 \mathrm{~kg} \mathrm{ha}^{-1}$ de $\mathrm{K}$ aplicado em faixa contínua $(40 \mathrm{~cm})$ nas entrelinhas, 6 meses após plantio e ; $42 \mathrm{~kg} \mathrm{ha}^{-1}$ de $\mathrm{K}$ aplicado em faixa contínua nas entrelinhas, 12 meses após plantio;

Tratamento 3: $34 \mathrm{~kg} \mathrm{ha}^{-1}$ de $\mathrm{K}$ aplicado ao redor das mudas, 45 dias após plantio das mudas ; $56 \mathrm{~kg} \mathrm{ha}^{-1}$ de $\mathrm{K}$ aplicado em faixa contínua $(40 \mathrm{~cm})$ nas entrelinhas, 6 meses após plantio e ; $22 \mathrm{~kg} \mathrm{ha}^{-1}$ de $\mathrm{K}$ aplicado em faixa contínua nas entrelinhas, 12 meses após plantio;

Tratamento 4: $44 \mathrm{~kg} \mathrm{ha}^{-1}$ de $\mathrm{K}$ aplicado ao redor das mudas 45 dias após plantio e ; $44 \mathrm{~kg} \mathrm{ha}^{-1}$ de $\mathrm{K}$ aplicado em faixa contínua $(40 \mathrm{~cm}$ ) nas entrelinhas, 12 meses após plantio.

Outros tratamentos também foram estabelecidos na área, uma vez que o trabalho faz parte de um projeto mais amplo firmado por contrato entre o Departamento de Engenharia Florestal da ESALQ/USP, Instituto de Pesquisas e Estudos Florestais (IPEF) e SABESP. Os demais tratamentos não foram aqui avaliados tendo em vista que fogem aos objetivos propostos.

As quantidades de carbono $(\mathrm{C})$, nitrogênio $(\mathrm{N})$, cádmio $(\mathrm{Cd})$, crômio $(\mathrm{Cr})$, cobre $(\mathrm{Cu})$, níquel $(\mathrm{Ni})$ e Zinco $(\mathrm{Zn})$ adicionadas ao solo via biossólido aplicado em diferentes doses estão apresentadas na Tabela 10. 
Tabela 10 Quantidades de carbono, nitrogênio total, nitrogênio inorgânico e metais pesados $(\mathrm{Cd}, \mathrm{Cr}, \mathrm{Cu}, \mathrm{Ni}$ e $\mathrm{Zn}$ ) adicionados ao solo via doses de biossólido.

\begin{tabular}{cccc}
\hline & \multicolumn{2}{c}{ Dose de biossólido } \\
& 10 & 20 & 40 \\
\hline & 1651 & 3302 & 6604 \\
Carbono $\left(\mathrm{kg} \mathrm{ha}^{-1}\right)$ & 153 & 307 & 614 \\
$\mathrm{~N}$-total $\left(\mathrm{kg} \mathrm{ha}^{-1}\right)$ & 14 & 28 & 56 \\
$\mathrm{~N}$-inorgânico $\left(\mathrm{kg} \mathrm{ha}^{-1}\right)$ & 140 & 280 & 560 \\
$\mathrm{Cd}\left(\mathrm{g} \mathrm{ha}^{-1}\right)$ & 3780 & 7560 & 15120 \\
$\mathrm{Cr}\left(\mathrm{g} \mathrm{ha}^{-1}\right)$ & 394 & 788 & 1576 \\
$\mathrm{Cu}\left(\mathrm{g} \mathrm{ha}^{-1}\right)$ & 2270 & 4540 & 9080 \\
$\mathrm{Ni}\left(\mathrm{g} \mathrm{ha}^{-1}\right)$ & 15550 & 31100 & 62200 \\
$\mathrm{Zn}\left(\mathrm{g} \mathrm{ha}^{-1}\right)$ & & $\mathrm{Mg} \mathrm{ha}^{-1}$ &
\end{tabular}

\subsection{Condução do experimento}

Amostragens do solo foram feitas em 5 épocas: 30, 60, 120, 180 e 360 dias após aplicação do biossólido. Amostras simples foram coletadas em 5 pontos nas entrelinhas dentro de cada parcela experimental (Figura 2), com auxílio de um trado tipo "holandês" com $120 \mathrm{~cm}$ de haste e $10 \mathrm{~cm}$ de ponta. As amostras simples foram misturadas e obtidas, para cada profundidade, 2 amostras compostas. Uma das amostras compostas era imediatamente armazenada sob refrigeração $\left(5^{\circ} \mathrm{C}\right)$ para posterior determinação da concentração de nitrogênio inorgânico. A outra era seca ao ar, peneirada (malha $2 \mathrm{~mm}$ ), homogeneizada e encaminhada para laboratório para as determinações analíticas previstas.

Até 180 dias após aplicação do biossólido a amostragem do solo foi feita nas profundidades de 0-30, 30-60 e 60-90 cm. Na última época de amostragem, 360 dias após aplicação do biossólido, as profundidades amostradas foram 0-10, 10-20, 20-30, 30-60 e 60-90 cm. Esse procedimento na última época de amostragem foi adotado para deteç̧ão de possíveis variações nos teores de $\mathrm{N}$ e metais pesados ( $\mathrm{Cd}, \mathrm{Cr}, \mathrm{Cu}, \mathrm{Ni}$ e $\mathrm{Zn}$ ) em menores camadas do solo. 
Amostras de folhas dos eucaliptos foram coletadas 360 dias após aplicação do biossólido aleatoriamente do terço superior das copas de 5 a 6 árvores localizadas dentro da área útil das parcelas experimentais. A coleta das folhas foi feita com auxílio de podão, devido a altura das árvores (em torno de 4-5 m). Após a coleta, o material foi seco a $60{ }^{\circ} \mathrm{C}$ até massa constante, moído em moinho tipo "Wiley" e encaminhado para análise das concentrações de $\mathrm{N}$ e dos metais $\mathrm{Cd}, \mathrm{Cr}, \mathrm{Cu}, \mathrm{Ni}$ e $\mathrm{Zn}$.

Durante o período experimental, diariamente foram coletados dados pluviais e de temperatura pelo posto meteorológico localizado na própria Estação Experimental da ESALQ/USP em Itatinga-SP. Os dados médios mensais de pluviosidade e temperatura durante o período experimental podem ser observados na Figura 4, assim como também a precipitação média calculada com dados de 1990 a 1996, que estão apresentados no boletim meteorológico do Instituto de Pesquisas e Estudos Florestais - IPEF (1997).

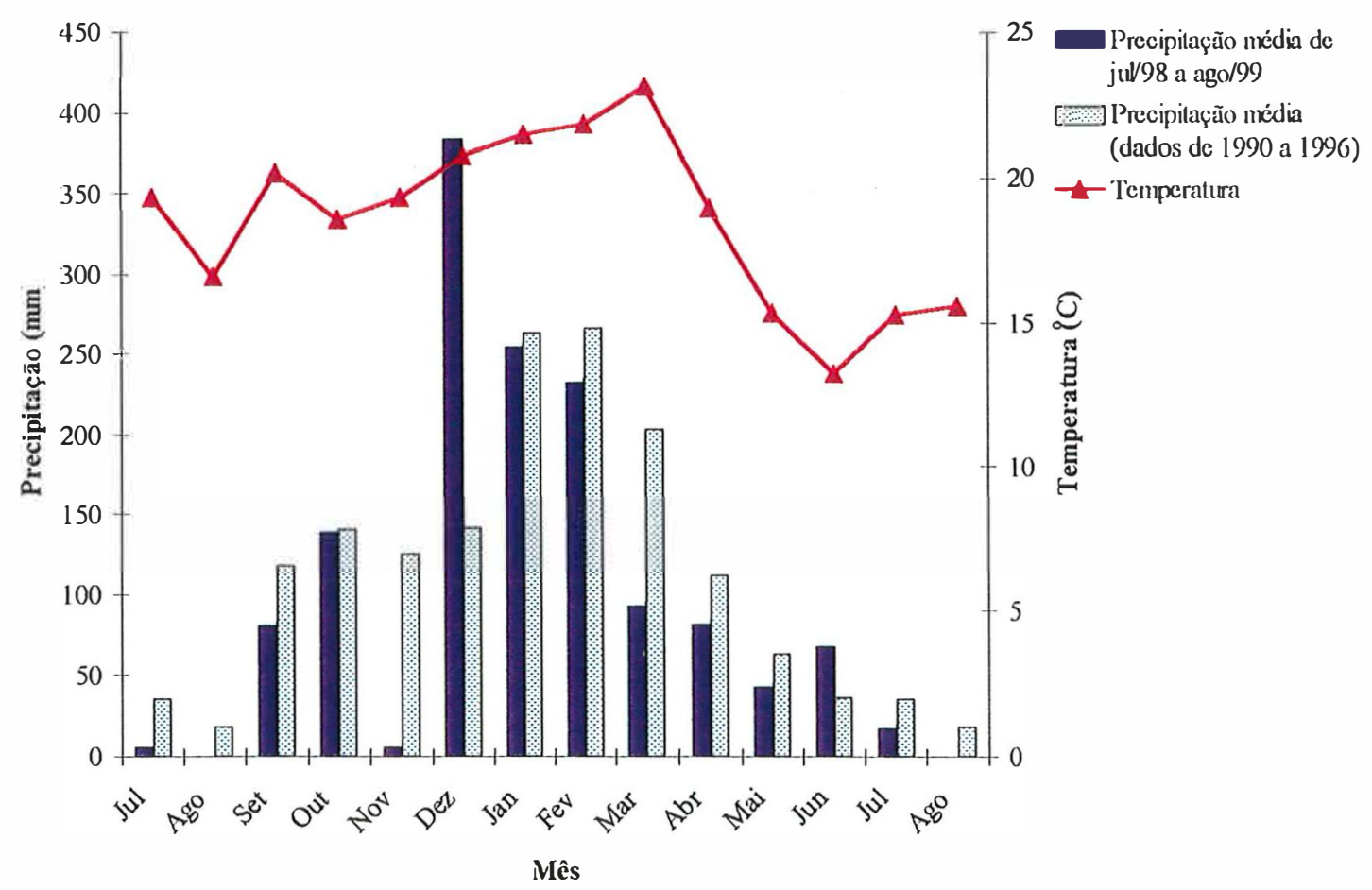

Figura 4 Precipitação e temperatura média mensal durante o período experimental (Jul/98 a Ago/99), e precipitação média calculada com dados de 1990 a 1996. 


\subsection{Análises realizadas}

\subsubsection{Amostras de terra}

Nas amostras coletadas aos 30, 60, 120 e 180 dias após aplicação do biossólido foram determinadas as concentrações de $\mathrm{N}$-inorgânico (nítrico+amoniacal) segundo a metodologia proposta por Mulvaney (1996) e dos metais pesados $\mathrm{Cd}, \mathrm{Cr}, \mathrm{Cu}, \mathrm{Ni}$ e $\mathrm{Zn}$ removidos pelo extrator Mehlich 3 (Mehlich, 1984). Nas amostras coletadas 360 dias após aplicação do biossólido, além das análises realizadas para as demais épocas, foram determinadas as concentrações totais de $\mathrm{N}$, de acordo com metodologia de Alcarde \& Chitolina (1991), e dos metais pesados $\mathrm{Cd}, \mathrm{Cu}, \mathrm{Cr}, \mathrm{Ni}$ e $\mathrm{Zn}$ extraídos com água régia segundo metodologia de Abreu et al. (1996).

A quantificação dos metais nos extratos obtidos com os extratores Mehlich 3 e água régia foi feita por espectrofotometria de absorção atômica convencional com chama.

Em todas as amostras de terra coletadas durante o período experimental foram feitas análises químicas para fins de fertilidade segundo Raij \& Quaggio (1983), para auxiliar na interpretação dos resultados.

\subsubsection{Amostras do tecido foliar}

Nas amostras de folha coletadas 360 dias após aplicação do biossólido foram determinadas as concentrações de $\mathrm{N}$ e metais pesados $(\mathrm{Cd}, \mathrm{Cr}, \mathrm{Cu}, \mathrm{Ni}$ e $\mathrm{Zn})$.

As concentrações dos metais pesados no tecido foliar foram medidas em extrato nítrico-perclórico (Sarruge \& Haag, 1974), sendo a determinação analítica feita por espectrofotometria de absorção atômica convencional com chama.

$\mathrm{O}$ teor de $\mathrm{N}$ foi determinado em extrato sulfúrico pelo método de micro Kjeldahl (Sarruge \& Haag, 1974). 


\subsection{Variáveis avaliadas}

\subsubsection{Metais pesados no solo}

Foi avaliada pelos resultados das determinações dos teores trocáveis (extrator Mehlich 3) e totais (extrator água régia) de $\mathrm{Cd}, \mathrm{Cr}, \mathrm{Cu}, \mathrm{Ni}$ e $\mathrm{Zn}$ presentes nas amostras de terra coletadas ao longo do período experimental.

\subsection{2 $\mathrm{N}-\mathrm{NO}_{3}{ }^{-}$no solo}

Foi avaliada pelos resultados das determinações dos teores de $\mathrm{N}$-inorgânico (nítrico + amoniacal) nas amostras de terra coletadas nas várias profundidades ao longo do período experimental.

Estudos prévios indicaram que $97 \%$ do $\mathrm{N}$-inorgânico no solo estudado estava na forma de nitrato, por isso a avaliação do $\mathrm{N}^{-\mathrm{NO}_{3}}{ }^{-}$foi feita com os dados de Ninorgânico. Essa constatação está de acordo com Medalie et al. (1994), que encontraram

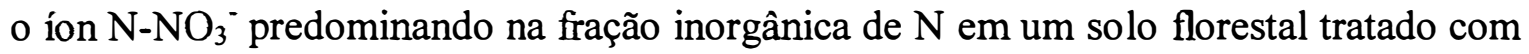
biossólido.

\subsubsection{N-total no solo}

Foi avaliado pelos resultados da determinação dos teores totais de $\mathrm{N}$ presentes nas amostras de terra coletadas 360 dias após aplicação do biossólido. 


\subsubsection{Fitodisponibilidade do $\mathrm{N}$ e dos metais $\mathrm{Cd}, \mathrm{Cr}, \mathrm{Cu}$, $\mathrm{Ni}$ e $\mathrm{Zn}$}

A fitodisponibilidade do $\mathrm{N}$ e dos metais $\mathrm{Cd}, \mathrm{Cr}, \mathrm{Cu}, \mathrm{Ni}$ e $\mathrm{Zn}$ foi avaliada pela presença desses elementos no tecido foliar das árvores de $E$. grandis.

Também foram feitas análises de correlações estatísticas entre as concentrações do elemento no tecido foliar e concentrações nas amostras de terra (camada 0-10 cm) coletadas 360 dias após aplicação do biossólido.

\subsection{Tratamen to estatístico dos dados obtidos}

O delineamento adotado foi o de blocos ao acaso, com 4 blocos e 4 tratamentos (doses de biossólido). As análises estatísticas foram realizadas para cada profundidade do solo amostrada, de modo a verificar possíveis efeitos das doses de biossólido sobre as variáveis estudadas em cada profundidade.

O programa estatístico utilizado para fazer as análises de variância e regressões foi o SANEST.

Os quadros das análises de variância com os respectivos coeficientes de variação (C.V.), valor de F e probabilidade > F, estão apresentados nos Apêndices 1 a 6 .

\subsubsection{Dados obtidos até 180 dias após aplicação do biossólido.}

A análise estatística dos dados foi realizada de acordo com o quadro de variância apresentado na Tabela 11. Os dados foram analisados como parcelas subdivididas no tempo, em função das 4 primeiras épocas de amostragem do solo. 
Tabela 11 Modelo de análise de variância

\begin{tabular}{cc} 
Causas de Variação & Graus de Liberdade \\
\hline Bloco & 3 \\
Dose de biossólido & 3 \\
Resíduo A & 9 \\
(Parcelas) & $(15)$ \\
Épocas & 3 \\
Interação Dose de biossólido x Época & 9 \\
Resíduo B & 36 \\
\hline Total & 63 \\
\hline
\end{tabular}

\subsubsection{Dados obtidos 360 dias após aplicação do biossólido}

Os dados foram analisados de acordo com o quadro de variância apresentado na Tabela 12 . Os dados de solo foram analisados dentro de cada profundidade.

Tabela 12 Modelo de análise de variância.

\begin{tabular}{cc}
\hline Causas de Variação & Graus de Liberdade \\
\hline Bloco & 3 \\
Dose de biossólido & 3 \\
Resíduo & 9 \\
\hline Total & 15 \\
\hline
\end{tabular}

Foram realizadas análises estatísticas de correlação e determinadas equações de regressão entre as quantidades de $\mathrm{N}$ presentes nas folhas e as quantidades de $\mathrm{N}$-total e $\mathrm{N}-\mathrm{NO}_{3}{ }^{-}$do solo. $\mathrm{O}$ teor de metais presentes nas folhas foi correlacionado com o teor total do metal presente no solo e, no caso do $\mathrm{Cu}$ também com o teor trocável do elemento no solo. As análises de correlação foram feitas utilizando o programa Excel. 


\section{RESULTADOS E DISCUSSÃO}

Os resultados médios (4 blocos) das análises de terra realizadas para $\mathrm{pH}$, matéria orgânica (M.O.), e demais parâmetros de fertilidade do solo aos 360 dias (Tabela 13) mostram que o valor $\mathrm{pH}$ na camada $0-10 \mathrm{~cm}$ se manteve entre 3,8 e 4,1 independentemente do tratamento considerado. Para M.O. essa variação esteve entre 4 e $8 \mathrm{~g} \mathrm{dm}^{-3}$ de terra.

Confrontando os resultados da Tabela 13 para pH do solo, com os encontrados por Andrade et al. (1998) quando incorporaram $33 \mathrm{Mg} \mathrm{ha}^{-1}$ de biossólido (base seca) a um Latossolo Vermelho Escuro, provocando aumento do $\mathrm{pH}$ solo de 5,0 para 7,5 num período de 180 dias após aplicação do resíduo, vê-se que a reação do biossólido quando aplicado sobre a superficie do solo é lenta e, desse modo, um período de tempo extenso pode ser necessário para verificação dos efeitos do biossólido sobre parâmetros químicos e físico-químicos do solo. Esse comportamento é provavelmente devido ao menor contato das partículas de biossólido com o solo, e a difícil hidratação dessas partículas depois de "secas". 
Tabela 13 Resultados médios ( 4 blocos) das análises de terra para fins de fertilidade, realizada nas amostra coletadas 360 dias após aplicação do biossólido.

\begin{tabular}{|c|c|c|c|c|c|c|c|c|c|c|c|c|}
\hline Amostra* & $\mathrm{pH}$ & M.O. & $\bar{P}$ & $\mathrm{~K}$ & $\mathrm{Ca}$ & $\overline{\mathrm{Mg}}$ & $\mathrm{H}+\mathrm{Al}$ & $\overline{\mathrm{Al}}$ & $\overline{\mathrm{SB}}$ & $\mathrm{T}$ & V & $\mathrm{m}$ \\
\hline & $\mathrm{CaCl}_{2}$ & $\mathrm{gdm}-3$ & $\mathrm{mg} \mathrm{dm}^{-3}$ & $\overline{\cdots-\cdots-\cdots}$ & $\cdots$ & $-\cdots--n$ & molc dm & -3 & & $\bar{\cdots}$ & $\%$ & $\%$ \\
\hline T1 p.0-10 & 3,8 & 4 & 27 & 0,2 & 1 & 1 & 49 & 12 & 2 & 51 & 4 & 85 \\
\hline T1 p. $10-20$ & 3,8 & 3 & 24 & 0,2 & 1 & 1 & 48 & 11 & 2 & 50 & 4 & 83 \\
\hline T1 p.20-30 & 3,9 & 3 & 19 & 0,1 & 2 & 1 & 41 & 10 & 3 & 44 & 7 & 76 \\
\hline T1 p.30-60 & 3,9 & 2 & 14 & 0,1 & 1 & 1 & 34 & 7 & 2 & 36 & 6 & 77 \\
\hline T1 p.60-90 & 4,0 & 3 & 11 & 0,1 & 1 & 1 & 29 & 7 & 2 & 31 & 7 & 77 \\
\hline T2 p.0-10 & 3,8 & 8 & 29 & 0,3 & 10 & 1 & 61 & 12 & 11 & 72 & 16 & 52 \\
\hline T2 p. $10-20$ & 3,8 & 4 & 20 & 0,3 & 3 & 1 & 47 & 11 & 4 & 51 & 8 & 72 \\
\hline T2 p.20-30 & 3,9 & 5 & 16 & 0,3 & 3 & 1 & 41 & 9 & 4 & 45 & 9 & 68 \\
\hline T2 p.30-60 & 4,0 & 2 & 14 & 0,1 & 2 & 1 & 33 & 8 & 3 & 36 & 9 & 72 \\
\hline T2 p.60-90 & 4,0 & 2 & 12 & 0,1 & 3 & 1 & 29 & 6 & 4 & 33 & 12 & 59 \\
\hline T3 p.0-10 & 3,9 & 7 & 32 & 0,3 & 8 & 1 & 57 & 12 & 9 & 66 & 14 & 56 \\
\hline T3 p.10-20 & 3,9 & 4 & 22 & 0,2 & 3 & 1 & 50 & 11 & 4 & 54 & 8 & 72 \\
\hline T3 p.20-30 & 3,9 & 4 & 17 & 0,1 & 2 & 1 & 37 & 10 & 3 & 40 & 8 & 76 \\
\hline T3 p.30-60 & 3,9 & 5 & 14 & 0,1 & 1 & 1 & 35 & 8 & 2 & 37 & 6 & 79 \\
\hline T3 p.60-90 & 4,0 & 3 & 9 & 0,2 & 1 & 1 & 30 & 6 & 2 & 32 & 7 & 73 \\
\hline T4 p.0-10 & 4,1 & 6 & 31 & 0,4 & 17 & 1 & 54 & 7 & 18 & 72 & 25 & 28 \\
\hline T4 p. $10-20$ & 4,0 & 6 & 18 & 0,3 & 6 & 1 & 42 & 9 & 7 & 49 & 15 & 55 \\
\hline T4 p.20-30 & 3,9 & 5 & 16 & 0,1 & 5 & 1 & 40 & 9 & 6 & 46 & 13 & 60 \\
\hline T4 p.30-60 & 4,0 & 4 & 12 & 0,1 & 3 & 1 & 32 & 7 & 4 & 36 & 11 & 63 \\
\hline T4 p.60-90 & 4,1 & 3 & 9 & 0,1 & 3 & 1 & 27 & 6 & 4 & 31 & 13 & 59 \\
\hline
\end{tabular}




\subsection{Metais pesados no solo}

\subsubsection{Cádmio e Níquel}

Os teores trocáveis e totais de $\mathrm{Cd}$ e Ni no solo estiveram abaixo do limite de determinação do método analítico utilizado. Apesar de não terem sido determinados no solo, é impróprio afirmar que esses metais não estão presentes, mas é correto afirmar que a concentração no extrato para análise foi menor que $0,08 \mathrm{mg} \mathrm{L}^{-1}$, ou seja os teores totais de $\mathrm{Cd} \mathrm{e} \mathrm{Ni}$ foram inferiores a $8 \mathrm{mg} \mathrm{kg}^{-1}$ de terra e os teores trocáveis inferiores a $0,8 \mathrm{mg} \mathrm{kg}^{-1}$ de terra.

\subsubsection{Crômio}

A quantidade de $\mathrm{Cr}$ removido pelo extrator Mehlich 3 esteve abaixo do limite de determinação do método analítico utilizado.

Os teores totais do elemento no solo após 360 dias da aplicação do biossólido são apresentados na Tabelal 4 .

Tabela 14 Cr-total nas amostras de terra, nas 5 profundidades, após 360 dias da aplicação do biossólido. Resultados médios dos 4 blocos analisados.

\begin{tabular}{|c|c|c|c|c|c|c|}
\hline \multirow[b]{2}{*}{ Doses de biossólido } & & \multicolumn{5}{|c|}{ Profundidade $(\mathrm{cm})$} \\
\hline & & $0-10$ & $10-20$ & $20-30$ & $30-60$ & $60-90$ \\
\hline $\mathrm{Mg} \mathrm{ha}^{-1}$ & & 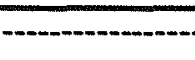 & (n) & $--\mathrm{mg} \mathrm{kg}^{-1}$ & 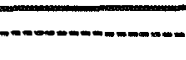 & $-\ldots$ \\
\hline 0 & & 12,46 & 13,42 & 13,71 & 14,91 & 15,07 \\
\hline 10 & & 13,40 & 13,64 & 15,84 & 15,09 & 15,87 \\
\hline 20 & & 14,24 & 12,97 & 13,53 & 16,70 & 17,39 \\
\hline 40 & & 12,57 & 14,51 & 15,62 & 17,07 & 18,44 \\
\hline Coeficiente de & Linear & 0,000 (n.s.) & 0,429 (n.s.) & 0,178 (n.s.) & 0,841 (n.s.) & 0,954 (n.s.) \\
\hline determinação $\left(\mathrm{R}^{2}\right)$ & Quadrático & $0,959 * *$ & 0,775 (n.s.) & 0,187 (n.s.) & 0,873 (n.s.) & 0,9767 (n.s.) \\
\hline
\end{tabular}


Somente na camada de $0-10 \mathrm{~cm}$ foi observado efeito significativo do biossólido, sobre a concentração total de $\mathrm{Cr}$ no solo. Em solos ácidos, como o utilizado neste estudo ( $\mathrm{pH}=3,8-4,1)$, a forma $\mathrm{Cr}^{+3}$ é favorecida, principalmente devido a reação de redução do $\mathrm{Cr}$ (VI), tendo como fonte de elétrons a matéria orgânica (Kabata-Pendias \& Pendias, 1995). $\mathrm{O} \mathrm{Cr}^{+3}$ é pouco móvel e inerte no solo em comparação a outros metais (Soon \& Abboud, 1993), o que pode explicar o acúmulo do elemento na camada mais superficial do solo.

\subsubsection{Cobre}

Os resultados obtidos para a concentração de Cu-trocável nas amostras de terra, coletadas da camada 0-30 cm durante os primeiros 180 dias após aplicação do biossólido (Tabela 15), mostram que não houve efeito das doses sobre essa forma de $\mathrm{Cu}$, assim como também não houve efeito da época.

Tabela 15 Cu-trocável na camada de $0-30 \mathrm{~cm}$ do solo durante os primeiros 180 dias após aplicação do biossólido. Resultados médios dos 4 blocos analisados.

\begin{tabular}{cccccc}
\hline & \multicolumn{3}{c}{ Dias após a aplicação do biossólido } & Média \\
\cline { 2 - 4 } Doses de biossólido & 30 & 60 & 120 & 180 & Tratamentos \\
\hline $\mathrm{Mg} \mathrm{ha}^{-1}$ & & & & 1,03 \\
0 & 1,15 & 1,00 & 0,92 & 0,95 & 1,01 \\
10 & 0,77 & 0,77 & 1,00 & 1,05 & 1,08 \\
20 & 1,10 & 1,05 & 1,02 & 1,07 & 1,00 \\
40 & 1,07 & 1,07 & 0,90 & 1,00 & 0,057 (n.s.) \\
Coeficiente de & Linear & & & & 0,450 (n.s.) \\
\hline
\end{tabular}

(n.s.) Não foi significativo a $5 \%$ pelo teste $F$. 
$\mathrm{Na}$ profundidade $30-60 \mathrm{~cm}$, foi observada interação significativa entre os fatores dose e época. O desdobramento dessa interação (Figura 5) mostrou o efeito do fator época dentro da dose $10 \mathrm{Mg} \mathrm{ha}^{-1}$ de biossólido.

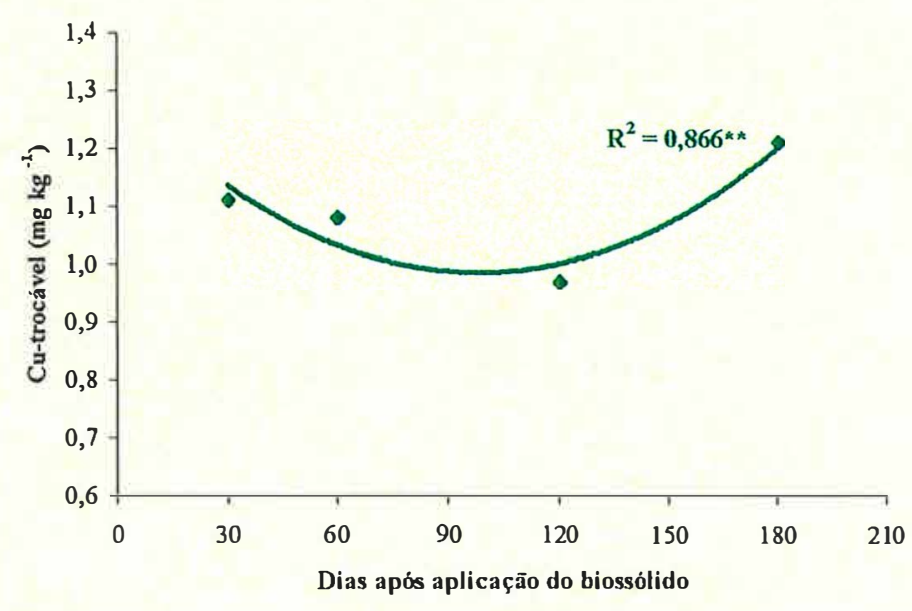

Figura 5 Variação do teor de Cu-trocável na profundidade de $30-60 \mathrm{~cm}$ do solo, durante 180 dias após adição de $10 \mathrm{Mg} \mathrm{ha}^{-1}$ de biossólido.

O efeito da época também foi observado sobre a concentração de Cu-trocável no solo na profundidade de $60-90 \mathrm{~cm}$ (Figura 6), independentemente da dose aplicada. Essa mobilidade do $\mathrm{Cu}$, provavelmente em função de chuvas no local do experimento (Figura 4), não tem sido observada por outros autores. Além disso, a movimentação do $\mathrm{Cu}$ pode ser atribuída ao passagem preferencial de água e partículas por canais que se estabelecem no solo em função do tipo de solo e do sistema radicular das plantas (McBride et al., 1997). 


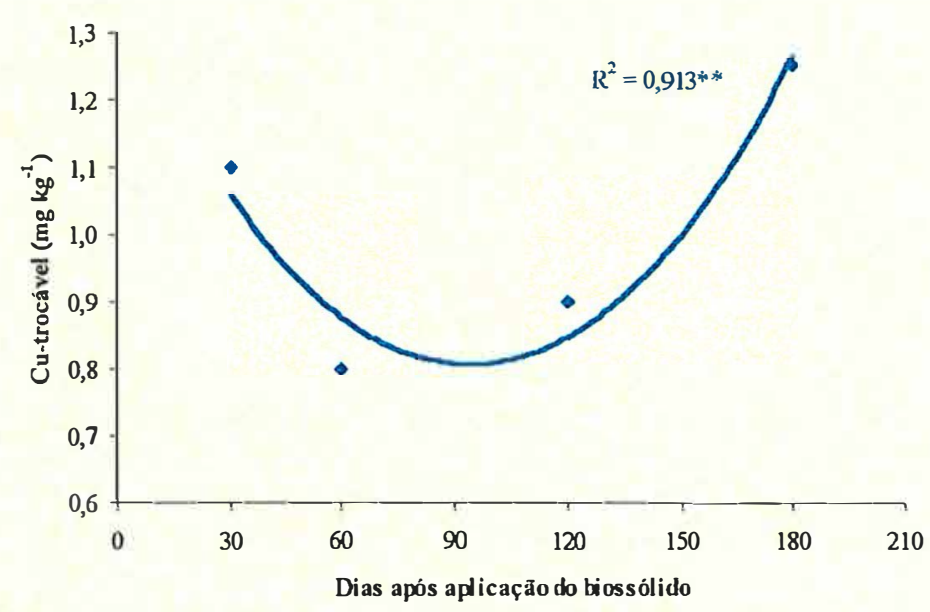

Figura 6 Cu-trocável na profundidade $60-90 \mathrm{~cm}$ do solo, em função das épocas de amostragem.

Os resultados para Cu-trocável determinados na camada $0-10 \mathrm{~cm}$ do solo mostraram efeito das doses, após 360 dias da aplicação do biossólido (Tabela 16). Nas demais profundidades não houve efeito das doses de biossólido sobre o Cu-trocável do solo, o que pode ser explicado pela baixa movimentação do elemento, que tende a formar complexos altamente estáveis com ácidos húmicos e outros ligantes orgânicos (Hughes, 1981; Landonin \& Margolina, 1997; Melo et al., 1997). Mattiazzo (1994) trabalhando em colunas de lixiviação com quatro diferentes solos ácidos e onde o elemento havia sido adicionado sob a forma de sal, observou que o elemento ficou retido na camada de $0-20 \mathrm{~cm}$. 
Tabela 16 Cu-trocável no solo, nas 5 profundidades, após 360 dias da aplicação do biossólido. Resultados médios dos 4 blocos analisados.

\begin{tabular}{|c|c|c|c|c|c|c|}
\hline \multirow[b]{2}{*}{ Doses de biossólido } & & \multicolumn{5}{|c|}{ Profundidade $(\mathrm{cm})$} \\
\hline & & $0-10$ & $10-20$ & $20-30$ & $30-60$ & $60-90$ \\
\hline $\mathrm{Mgha}$ & & & & $-\mathrm{mg} \mathrm{kg}{ }^{-1}$ & & \\
\hline 0 & & 1,5 & 1,5 & 1,5 & 2,0 & 2,0 \\
\hline 10 & & 1,5 & 1,2 & 2,0 & 1,7 & 2,0 \\
\hline 20 & & 1,5 & 1,7 & 1,7 & 1,7 & 2,0 \\
\hline 40 & & 2,5 & 2,0 & 2,0 & 2,2 & 2,0 \\
\hline Coeficiente de & Linear & $0,772 *$ & 0,691 (n.s.) & 0,439 (n.s.) & 0,314 (n.s.) & - \\
\hline determinação $\left(\mathrm{R}^{2}\right)$ & Quadrático & 0,988 (n.s.) & 0,738 (n.s.) & 0,524 (n.s.) & 0,997 (n.s.) & - \\
\hline
\end{tabular}

(n.s.) Não foi significativo a $5 \%$ pelo teste $\mathrm{F}$

* Significativo a $5 \%$ pelo teste $\mathrm{F}$;

- Indica que não foi possível fazer análise de regressão com os dados obtidos.

As doses de biossólido não contribuíram para elevação do teor total de $\mathrm{Cu}$ no solo após 360 dias da aplicação (Tabela 17), o que pode ser explicado pela forma de aplicação do biossólido nesse experimento, ou seja em superfície, sem posterior incorporação ao solo.

Quando se compara teor total de $\mathrm{Cu}$ com o removido pelo extrator Mehlich 3, aos 360 dias e onde foi observado efeito do biossólido aumentando o teor trocável do elemento, pode-se considerar que as doses de biossólido provocaram uma redistribuição entre as formas de $\mathrm{Cu}$ no solo, acabando por incrementar as formas do elemento removidas por aquele extrator. 
Tabela 17 Cu-total no solo, nas 5 profundidades, 360 dias após aplicação do biossólido. Resultados médios dos 4 blocos analisados.

\begin{tabular}{|c|c|c|c|c|c|c|}
\hline \multirow[b]{2}{*}{ Doses de biossólido } & & \multicolumn{5}{|c|}{ Profundidade $(\mathrm{cm})$} \\
\hline & & $0-10$ & $10-20$ & $20-30$ & $30-60$ & $60-90$ \\
\hline $\mathrm{Mgha}^{-1}$ & & - & 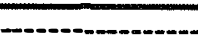 & $-\mathrm{mg} \mathrm{kg}^{-1}$ & & \\
\hline 0 & & 13,48 & 13,44 & 12,92 & 14,13 & 16,17 \\
\hline 10 & & 12,89 & 14,20 & 15,03 & 13,52 & 14,61 \\
\hline 20 & & 12,17 & 12,71 & 12,48 & 14,85 & 17,41 \\
\hline 40 & & 13,38 & 13,95 & 15,06 & 16,53 & 18,20 \\
\hline Coeficiente de & Linear & 0,001 (n.s.) & 0,013 (n.s.) & 0,199 (n.s.) & 0,822 (n.s.) & 0,180 (n.s.) \\
\hline determinação $\left(\mathrm{R}^{2}\right)$ & Quadrático & 0,922 (n.s.) & 0,156 (n.s.) & 0,238 (n.s.) & 0,917 (n.s.) & 0,698 (n.s.) \\
\hline
\end{tabular}

(n.s.) Não significativo a $5 \%$ pelo teste F;

\subsubsection{Zinco}

Não foi detectada a presença de Zn-trocável nas amostras de terra coletadas nas várias profundidades e épocas de amostragem.

Os teores totais do elemento, determinados 360 dias após aplicação do biossólido (Tabela 18), indicam o efeito significativo das doses aplicadas sobre o teor de Zn-total na profundidade de $30-60 \mathrm{~cm}$, com o acúmulo de $\mathrm{Zn}$ nessa camada do solo em função da dose. 
Tabela 18 Zn-total no solo, nas 5 profundidades, 360 dias após a aplicação do biossólido. Resultados expressos como média dos 4 blocos analisados.

\begin{tabular}{|c|c|c|c|c|c|c|}
\hline \multirow[b]{2}{*}{ Doses de biossólido } & & \multicolumn{5}{|c|}{ Profundidade $(\mathrm{cm})$} \\
\hline & & $0-10$ & $10-20$ & $20-30$ & $30-60$ & $60-90$ \\
\hline $\mathrm{Mgha}^{-1}$ & & & & $-\mathrm{mg} \mathrm{kg}^{-1}$ & & \\
\hline 0 & & 12,20 & 12,42 & 12,39 & 12,85 & 12,45 \\
\hline 10 & & 12,13 & 10,82 & 12,72 & 11,69 & 22,76 \\
\hline 20 & & 20,03 & 15,90 & 11,43 & 15,40 & 16,06 \\
\hline 40 & & 13,43 & 14,23 & 15,63 & 16,01 & 18,19 \\
\hline Coeficiente de & Linear & 0,061 (n.s.) & 0,296 (n.s.) & 0,538 (n.s.) & $0,670 *$ & 0,076 (n.s.) \\
\hline determinação $\left(\mathrm{R}^{2}\right)$ & Quadrático & 0,542 (n.s.) & 0,364 (n.s.) & 0,875 (n.s.) & 0,670 (n.s.) & 0,276 (n.s.) \\
\hline
\end{tabular}

(n.s.) Não significativo a $5 \%$ pelo teste F;

* Significativo a $5 \%$ pelo teste $\mathrm{F}$.

O aumento do Zn-total na camada $30-60 \mathrm{~cm}$ do solo, em função da dose de biossólido aplicada, foi indicativo da movimentação do elemento no perfil vertical do solo, comportamento este também verificado por Mattiazzo (1994) em estudo com o elemento aplicado sob forma de sal a diferentes solos ácidos. Resultados semelhantes sobre mobilidade do $\mathrm{Zn}$ aplicado via biossólido foram obtidos por Zhu \& Alva (1993) que observaram alta correlação entre carbono orgânico dissolvido (C.O.D.) e $\mathrm{Zn}$ em lixiviados, concluindo que o $\mathrm{Zn}$ pode lixiviar no perfil do solo na forma de complexos com substâncias orgânicas solúveis.

\section{$4.2 \mathrm{~N}-\mathrm{NO}_{3}^{-}$no solo}

Durante os primeiros 180 dias não foram observados efeitos das doses de biossólidos sobre os teores de $\mathrm{N}_{-} \mathrm{NO}_{3}{ }^{\circ}$ no solo nas várias profundidades amostradas.

O efeito significativo das épocas de amostragem pode ser observado na Figura 7. Nos primeiros 70-100 dias de avaliação (agosto-outubro/98) houve uma queda nos teores de $\mathrm{N}_{-} \mathrm{NO}_{3}{ }^{\circ}$. Após esse período os teores, nas várias profundidades amostradas, 
tenderam a crescer até os 180 dias (outubro/98-janeiro/99) após aplicação do biossólido.

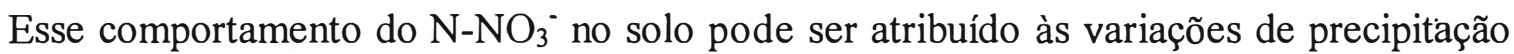
e temperatura ocorridas no período considerado (Figura 4). É interessante notar que o comportamento verificado para Cu-trocável na profundidade $60-90 \mathrm{~cm}$ do solo (Figura 6) foi muito semelhante ao ocorrido com o $\mathrm{N}^{-\mathrm{NO}_{3}}{ }^{-}$, comprovando essa variação sazonal em função das chuvas e temperatura.

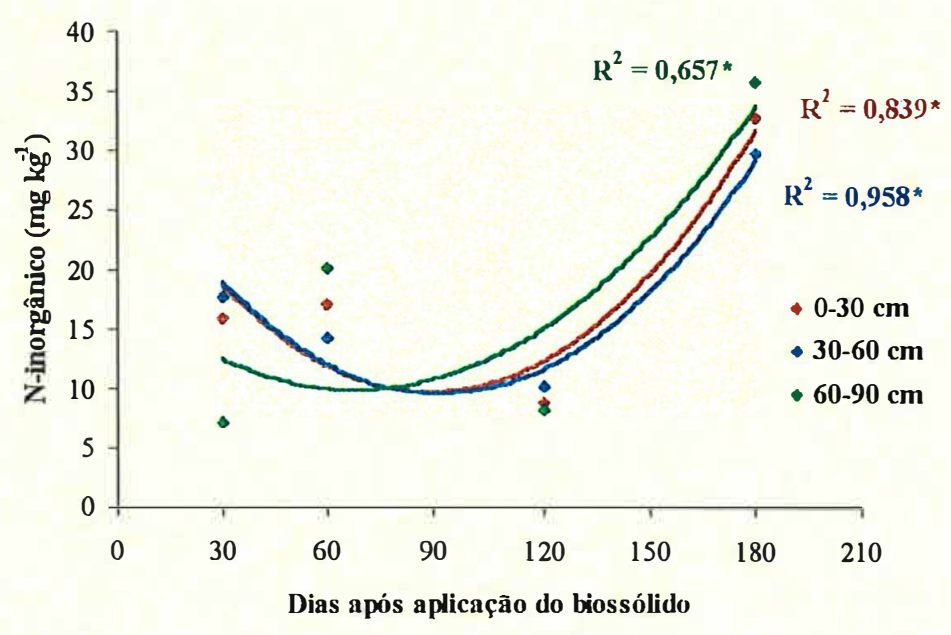

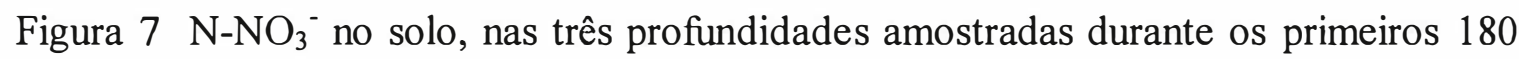
dias após aplicação do biossólido

$\mathrm{Na}$ amostragem realizada aos 360 dias também não foram observados efeitos das doses sobre o teor de $\mathrm{N}-\mathrm{NO}_{3}{ }^{-}$, mesmo tendo sido feita a amostragem em menores profundidades na camada de $0-30 \mathrm{~cm}$ do solo (Tabela 19 ). 


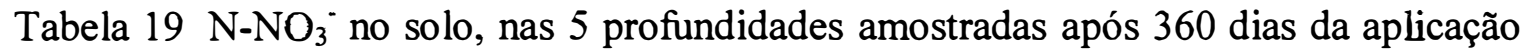
do biossólido. Resultados expressos como média dos 4 blocos avaliados.

\begin{tabular}{|c|c|c|c|c|c|c|}
\hline \multirow[b]{2}{*}{ Doses de biossólido } & & \multicolumn{5}{|c|}{ Profundidade $(\mathrm{cm})$} \\
\hline & & $0-10$ & $10-20$ & $20-30$ & $30-60$ & $60-90$ \\
\hline $\mathrm{Mgha}^{-1}$ & & & - & $-\mathrm{mg} \mathrm{kg}^{-1}$ & 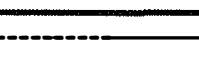 & \\
\hline 0 & & 18,80 & 14,97 & 23,11 & 28,69 & 32,12 \\
\hline 10 & & 44,70 & 41,01 & 43,57 & 20,44 & 26,89 \\
\hline 20 & & 20,62 & 37,02 & 16,23 & 63,49 & 36,24 \\
\hline 40 & & 15,84 & 29,93 & 27,30 & 20,18 & 16,97 \\
\hline Coeficiente de & Linear & 0,142 (n.s.) & 0,112 (n.s.) & 0,016 (n.s.) & 0,002 (n.s.) & 0,467 (n.s.) \\
\hline determinação $\left(\mathrm{R}^{2}\right)$ & Quadrático & 0,358 (n.s.) & 0,809 (n.s.) & 0,017 (n.s.) & 0,425 (n.s.) & 0,708 (n.s.) \\
\hline
\end{tabular}

(n.s.) Não significativo a $5 \%$ pelo teste F;

\subsection{N-total no solo}

As concentrações médias (4 blocos) de $\mathrm{N}$-total determinadas para as profundidades $0-10,10-20,20-30,30-60$ e $60-90 \mathrm{~cm}, 360$ dias após aplicação do biossólido são apresentadas na Tabela 20, onde se pode observar que não houve efeito do biossólido aplicado sobre o teor total desse elemento; resultado semelhante foi encontrado por Artiola \& Pepper (1992) quando aplicaram cerca de $12 \mathrm{Mg} \mathrm{ha}^{-1}$ ano $^{-1}$ (base seca) de lodo de esgoto líquido durante 5 anos. Pelo exame desta Tabela verifica-se que o teor total de $\mathrm{N}$ diminuiu com o aumento da profundidade à semelhança da matéria orgânica do solo (Tabela 13). Isso indica que não houve movimentação vertical de $\mathrm{N}$ no solo, em função da adição do biossólido. 
Tabela 20 N-total no solo, nas 5 profundidades amostradas 360 dias após aplicação do biossólido. Resultados médios dos 4 blocos amostrados.

\begin{tabular}{|c|c|c|c|c|c|c|}
\hline \multirow[b]{2}{*}{ Doses de biossólido } & & \multicolumn{5}{|c|}{ Profundidade $(\mathrm{cm})$} \\
\hline & & $0-10$ & $10-20$ & $20-30$ & $30-60$ & $60-90$ \\
\hline $\mathrm{Mgha}^{-1}$ & & & $-\ldots$ & $\mathrm{g} \mathrm{kg}^{-1}$ & $\ldots$ & 西- \\
\hline 0 & & 0,625 & 0,475 & 0,437 & 0,447 & 0,372 \\
\hline 10 & & 0,587 & 0,412 & 0,405 & 0,337 & 0,237 \\
\hline 20 & & 0,655 & 0,502 & 0,415 & 0,407 & 0,360 \\
\hline 40 & & 0,695 & 0,480 & 0,400 & 0,312 & 0,270 \\
\hline Coeficiente de & Linear & 0,684 (n.s.) & 0,108 (n.s.) & 0,593 (n.s.) & 0,526 (n.s.) & 0,151 (n.s.) \\
\hline determinação $\left(\mathrm{R}^{2}\right)$ & Quadrático & 0,755 (n.s.) & 0,113 (n.s.) & 0,711 (n.s.) & 0,530 (n.s.) & 0,159 (n.s.) \\
\hline
\end{tabular}

\subsection{Fitodisponibilidade dos metais pesados}

Entre os metais estudados, apenas foi possível determinar os teores de $\mathrm{Cu}, \mathrm{Ni}$ e $\mathrm{Zn}$ nas amostras foliares porém, para nenhum deles houve efeito do biossólido aplicado nas diferentes doses (Tabela 21 ). Isso indica, que com a aplicação desses elementos via biossólido em quantidades correspondentes a até $1,8 \mathrm{~kg} \mathrm{ha}^{-1}$ de $\mathrm{Cu} ; 9,1 \mathrm{~kg} \mathrm{ha}^{-1}$ de $\mathrm{Ni}$ e $62,2 \mathrm{~kg} \mathrm{ha}^{-1} \mathrm{de} \mathrm{Zn}$, esses metais não mostraram evidências de disponibilidade às plantas de Eucalyptus grandis.

A correlação feita para teores trocáveis de $\mathrm{Cu}$ no solo e teores desse elemento nas plantas não foi significativa a 5\%, sugerindo portanto, que o extrator Mehlich 3 não foi eficiente para avaliação da fitodisponibilidade de $\mathrm{Cu}$ às árvores de Eucalyptus grandis.

As correlações entre os teores totais de $\mathrm{Cu}$ e $\mathrm{Zn}$ no solo e teores desses metais nas plantas, também não foram significativas a $5 \%$. 
Tabela $21 \mathrm{Cu}, \mathrm{Ni}$ e Zn nas folhas de E. grandis 360 dias após aplicação do biossólido no solo. Resultados médios dos 4 blocos analisados.

\begin{tabular}{|c|c|c|c|c|}
\hline Doses de biossólido & & $\mathrm{Cu}$ & $\mathrm{Ni}$ & $\mathrm{Zn}$ \\
\hline $\mathrm{Mg} \mathrm{ha}^{-1}$ & & - -------------- & $--\mathrm{mg} \mathrm{kg}^{-1}$ & $\begin{array}{l}-\cdots-\cdots \\
-\cdots-\cdots\end{array}$ \\
\hline 0 & & 8,5 & 29,0 & 30,5 \\
\hline 10 & & 8,2 & 17,5 & 17,5 \\
\hline 20 & & 7,7 & 28,7 & 12,0 \\
\hline 40 & & 8,2 & 4,5 & 3,25 \\
\hline Coeficiente de & Linear & 0,121 (n.s.) & 0,613 (n.s.) & 0,092 (n.s.) \\
\hline determinação $\left(\mathrm{R}^{2}\right)$ & Quadrático & 0,845 (n.s.) & 0,070 (n.s.) & 0,990 (n.s.) \\
\hline
\end{tabular}

(n.s.) Não foi significativo a $5 \%$ pelo teste F;

\subsection{Fitodisponibilidade do $\mathrm{N}$}

Houve efeito significativo das doses de biossólido adicionadas ao solo sobre a concentração de $\mathrm{N}$ nas folhas (Figura 8 ), no entanto não se pode dizer que o $\mathrm{N}$ do biossólido supriu diretamente as plantas, pois o efeito pode ter sido sobre a mineralização da serrapilheira, visto que o biossólido não foi incorporado ao solo.

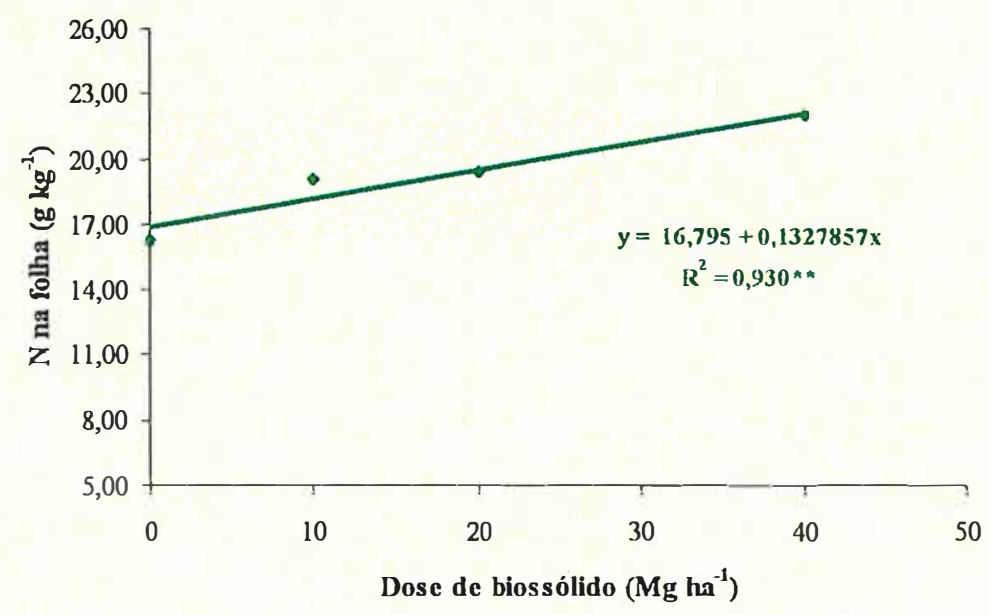

Figura 8 Aumento da concentração de $\mathrm{N}$ nas folhas de Eucalyptus grandis com a aplicação de doses de biossólido. 
Como não foram verificadas alterações nos teores de $\mathrm{N}$-total e $\mathrm{N}-\mathrm{NO}_{3}{ }^{-}$do solo e nem em parâmetros de fertilidade (Tabela 13) que poderiam contribuir para a elevação do teor de $\mathrm{N}$ das folhas, pode-se afirmar que nenhum desses parâmetros é um indicativo da fitodisponibilidade de $\mathrm{N}$, assim como se pode presumir que o $\mathrm{N}$ disponibilizado às plantas durante o período experimental foi principalmente em função do conteúdo inorgânico de $\mathrm{N}$ do biossólido.

Os teores de $\mathrm{N}$-total e $\mathrm{N}^{-\mathrm{NO}_{3}}{ }^{-}$na camada $0-10 \mathrm{~cm}$ do solo não tiveram correlação significativa com as concentrações presentes na folhas de Eucalyptus grandis no período experimental considerado (360 dias), o que mais uma vez reforça a afirmação de que nenhum desses parâmetros foi considerado adequado para se estimar a fitodisponibilidade de $\mathrm{N}$.

$\mathrm{O}$ efeito das doses crescentes de biossólido sobre o aumento do teor de $\mathrm{N}$ nas folhas de Eucalyptus grandis evidencia uma maior fitodisponibilidade de N, provocada pela aplicação do biossólido, o que concorda com Cox (1995) quando se considera culturas de ciclo longo, caso em que a necessidade de $\mathrm{N}$ pelas plantas é melhor sincronizada com a mineralização do $\mathrm{N}$ orgânico do biossólido. 


\section{APRECIAÇÃO GERAL DOS RESULTADOS OBTIDOS}

A aplicação de doses crescentes do biossólido, proporcionou aumento na concentração de $\mathrm{N}$ nas folhas de $E$. grandis, porém não alterou o teor total e inorgânico do nutriente no solo. Esse efeito somente sobre as plantas se deve provavelmente ao rápido crescimento inicial da espécie florestal e a lenta degradação da fração orgânica do biossólido, função principalmente da forma de aplicação do resíduo, em superfície, sem incorporação, o que reduziu o contato das partículas de biossólido com o solo e, por conseqüência, os processos de degradação por microrganismos do solo.

As doses de biossólido não tiveram efeito sobre a disponibilidade de $\mathrm{Cd}, \mathrm{Cr}$, $\mathrm{Cu}, \mathrm{Ni}$ e $\mathrm{Zn}$ às plantas de $E$. grandis, porém resultados mais conclusivos só poderão ser obtidos ao longo dos anos, uma vez que a cultura estudada permanece por cerca de 7 anos no campo, antes do corte. Quanto a movimentação desses metais no perfil do solo, $\mathrm{Zn}$ foi o único a se movimentar, o que pode ser observado pela acumulação do elemento na camada 30-60 cm do solo (Tabela 18), 360 dias após aplicação do resíduo. $\mathrm{O} \mathrm{Cr}$ acumulou na camada mais superficial $(0-10 \mathrm{~cm})$ por estar presente no solo numa forma inerte e pouco móvel e; o efeito do biossólido sobre o $\mathrm{Cu}$ foi provavelmente indireto,

provocando uma redistribuição entre as formas do metal no solo, o que não incrementou sua absorção pelas plantas, mas aumentou a quantidade removida das amostras de terra pelo extrator Mehlich 3. Dessa forma, o extrator Mehlich 3 não foi eficiente na avaliação da disponibilidade do $\mathrm{Cu}$ às plantas de $E$. grandis.

A aplicação do biossólido na superfície do solo, sem incorporação, pode trazer, em função da menor degradação do resíduo, uma disponibilidade lenta de nutrientes às plantas e menor risco ambiental. Mais estudos são necessários para avaliar 
até que ponto doses seguras de biossólido podem suprir adequadamente a necessidade das plantas em nutrientes. 


\section{CONCLUSÕES}

Tendo em vista os resultados obtidos conclui-se que:

- Não houve movimentação de nitratos no perfil vertical do solo, provocada pela adição de biossólido em doses de até $40 \mathrm{Mg} \mathrm{ha}^{-1}$;

- O único metal a se movimentar no perfil vertical do solo, em função da dose de biossólido aplicada, foi o $\mathrm{Zn}$;

- A aplicação de doses crescentes do biossólido, até $40 \mathrm{Mg} \mathrm{ha}^{-1}$, proporcionou aumento na disponibilidade de $\mathrm{N}$ às árvores de Eucalyptus grandis;

- Os metais $\mathrm{Cu}, \mathrm{Ni}$ e $\mathrm{Zn}$ não tiveram a fitodisponibilidade alterada em função das doses de biossólido aplicadas ao solo;

- São necessários estudos a longo prazo quando se considera o uso florestal do biossólido. 


\section{REFERÊNCIAS BIBLIOGRÁFICAS}

ABREU, M.F. de; BERTON, R.S.; ANDRADE, J.C. de. Comparison of methods to evaluete heavy metals in organic wastes. Communications in Soil Science and Plant Analysis, v.27, n.5-8, p.1125-1135, 1996.

ADRIANO, D.C. Trace elements in the terrestrial environment. New York: Springer-Verlag, 1986. 533p.

ALCARDE, J.C.; CHITOLINA, J.C. Determinação do nitrogênio total em solos pelo método da liga de Raney. Revista de Agricultura, v.66, n.1, p.97-106, 1991.

ANDRADE, C.A.; COSTA, F.G.; MATTIAZZO, M.E. Curvas de neutralização de lodo de esgoto e composto de lixo em Latossolo Vermelho Escuro. In: FERTIBIO 98; REUNIÃO BRASILEIRA DE FERTILIDADE DO SOLO E NUTRIÇÃO DE PLANTAS, 13.; REUNIÃO BRASILEIRA SOBRE MICORRIZAS, 7.; SIMPÓSIO BRASILEIRO DE MICROBIOLOGIA DO SOLO, 5.; REUNIÃO BRASILEIRA DE BIOLOGIA DO SOLO, 2., Caxambu, 1998. Resumos. Lavras: UFLA, SBCS, SBM, 1998. p.456.

ANFPC. Associação Nacional dos Fabricantes de Papel e Celulose. Relatório estatístico. São Paulo, 1985. 48p.

ANJOS, A.R.M. dos. Lixiviação de espécies químicas em latossolos sucessivamente tratados com biossólido e disponibilidade de metais pesados para plantas de milho. Piracicaba, 1999. 191p. Tese (Doutorado) - Escola Superior de Agricultura "Luiz de Queiroz", Universidade de São Paulo. 
ARTIOLA, J.F. Nonuniform leaching of nitrate and other solutes in a furrow-irrigated, sludge amended field. Communications in Soil Science and Plant Analysis, v.22, n.9-10, p.1013-1030, 1991.

ARTIOLA, J.F.; PEPPER, I.L. Longterm influence of liquid sewage sludge on the organic carbon and nitrogen content of a furrow-irrigated desert soil. Biology and Fertility of Soils, v. 14, p.30-36, 1992.

AYUSO, M.; HERNANDEZ, T.; GARCIA, C.; COSTA, F. Utilización d'un lodo aerobio como sustitutivo de fertilizantes fosforados inorgánicos. Suelo y Planta, v.2, p.271-280, 1992.

BARRETO, M.C.V.. Degradação da carga orgânica de diferentes resíduos e seus respectivos efeitos em alguns atributos químicos e físicos do solo. Piracicaba, 1995. 106p. Tese (Doutorado) - escola Superior de Agricultura "Luiz de Queiroz", Universidade de São Paulo.

BARROS, N.F.; NOVAIS, R.F.; CARDOSO, J.R.; MACEDO, P.R.O. Algumas relações solo-espécies de eucalipto em suas condições naturais. In: BARROS, N.F.; NOVAIS, R.F. (Ed.). Relação solo-eucalipto. Viçosa: Editora Folha de Viçosa, 1990. cap.1, p.1-24.

BERTON, R.S.; CAMARGO, VALADARES, J:M.A.S. Absorção de nutrientes pelo milho em resposta à adição de lodo de esgoto a cinco solos paulistas. Revista Brasileira de Ciência do Solo, v. 13, p. 187-192, 1989.

BERTON, R.S.; VALADARES, J.M.A.S.; CAMARGO, O.A.; BATAGLIA, O.C. Peletização do lodo de esgoto e adição de $\mathrm{CaCO}^{3}$ na produção de matéria seca e absorção de $\mathrm{Zn}, \mathrm{Cu}$ e Ni pelo milho em três latossolos. Revista Brasileira de Ciência do Solo, v.21, p.685-691, 1997. 
BERTONCINI, E.I. Mobilidade de metais pesados em solos tratados com lodo de esgoto. Piracicaba, 1997. 102p. Dissertação (Mestrado) - Escola Superior de Agricultura "Luiz de Queiroz", Universidade de São Paulo.

BERTONCINI, E.I.; MATTIAZZO, M.E. Lixiviação de metais pesados em solos tratados com lodo de esgoto. Revista Brasileira de Ciência do Solo, v.23, n.3, p.737-744, 1999.

BETTIOL, W.; CARVALHO, P.C.T. Lodo de esgoto como fertilizante para cultura do milho (Zea mays L.) híbrido HMDO7974. Fertilizantes, v.4, p.9-11, 1982.

BOYLE, M.; PAUL, E.A. Carbon and nitrogen mineralization kinetics in soil previously amended with sewage sludge. Soil Science Society American Journal, v.53, p.99-103, 1989.

BUNTING, A.H. Experiments on organic manures. Journal of Agricultural Science, v.60, p.121-140, 1963.

BURTON, A.J.; HART, J.B.; URIE, D.H. Nitrification in sludge-amended Michigan Forest soils. Journal of Environmental Quality, v.19, p.609-616, 1990

CAMARGO, O.A. de; MONIZ, A.C.; JORGE, J.A.; VALADARES, J.M.A.S. Métodos de análise química, mineralógica e física de solos do Instituto Agronômico de Campinas. Campinas: IAC, 1986. 94p. (IAC. Boletim Técnico, 106) 
CHANG, A.C.; HINESLY, T.D.; BATES, T.E.; DONER, H.E.; DOWDY, R.H.; RYAN, J.A. Effects of long term sludge application on accumulation of trace elements by crops. In: PAGE, A.L.; LOGAN, T.J.; RYAN, J.A. Land application of sludge-food chain implications. Chelsea: Lewis Publishers, 1987. Cap.4, p.5366.

CETESB. Aplicação de biossólido em áreas agrícolas - critérios para projeto e operação (Manual Técnico). São Paulo: CETESB, 1999. 35p.

COX, D.A. Pelletized sewage sludge as a fertilizer for containerized plants: plant growth and nitrogen leaching losses. Journal of Plant Nutrition, v.18, n.12, p. 2783-2795, 1995.

DA ROS, C.O. da; AITA, C.; CERETTA, C.A.; FRIES, M.R. Lodo de esgoto: efeito imediato no milheto e residual na associação aveia-ervilhaca. Revista Brasileira de Ciência do Solo, v.17, p.257-261, 1993.

DİAZ-BURGOS, M.A.; POLO, A. Variaciones de la fracción orgánica durante el compostaje de lodos de depuradoras. Suelo y Planta, v.1, p.453-466, 1991.

EPSTEIN, E.; KEANE, D.B.; MEISINGER, J.J.; LEGG, J.O. Mineralization of nitrogen from sewage sludge and sludge compost. Journal of Environmental Quality, v.7, n.2, p.217-221, 1978.

GAINES, T.P.; GAINES, S.T. Soil texture effect on nitrate leaching in soil percolates. Communications in Soil Science and Plant Analysis, v.25, n.13-14, p.2561-2570, 1994. 
GLÓRIA, N.A. Uso agronômico de resíduos. In: REUNIÃO BRASILEIRA DE FERTILIDADE DO SOLO E NUTRIÇÃO DE PLANTAS, 22., Piracicaba, 1992. Anais. Piracicaba: Fundação Cargill, 1992. p.195-212.

HART, J.B.; NGUYEN, P.V.; URIE, D.H.; BROCKWAY, D.G. Silvicultural use of wastewater sludge. Journal of Forestry, n.8, p. 17-24, 1988.

HENRY, C.L.; COLE, D.W.; HARRISON, R.B. Use of municipal sludge to restore and improve site productivity in forestry: The Pack Forest Sludge Research Program. Forest Ecology and Management, v.66, p.137-149, 1994.

HUGHES, M.K. Cycling of tracce metal in ecosystems. In: LEPP, N.W. (Ed.). Effexts of heavy metal pollution on plants. London: Applied Science Publishers, 1981, p.95-118.

IPEF. Boletim meteorológico EECF de Itatinga 1990/1996. Piracicaba: ESALQ/USP, 1997. 344p. (Boletim Técnico).

KABATA-PENDIAS, A.; PENDIAS; H. Trace elements in soils and plants. 3. ed. Boca Raton: CRP Press, 1985. 315p.

KROSS, B.C.; OLSON, M.L.; AYEBO, A.; JOHNSON, J.K. Humans. In: RECHCIGL, J.E. Impacts on biotic systems. London: Lewis Publishers, 1995. cap.6, p.153-203.

LANDONIN, D.V.; MARGOLINA, S.E. Interactions between humic acids and heavy metals. Eurasian Soil Science, v.30, n.7, p.710-715, 1997. 
LABRECQUE, M.; TEODORESCU, T.I.; DAIGLE, S. Effect of wastewater sludge on growth and heavy metal bioaccumulation of two Salix species. Plant and Soil, v.171, p.303-316, 1995.

LINDEMANN, W.C.; CARDENAS, M. Nitrogen mineralization potencial and nitrogen transformations of sludge-amended soil. Soil Science Society of American Journal, v.48, p.1072-1077, 1984.

LINDEMANN, W.C.; CONNELL, G.; URQUHART, N.S. Previous sludge addition effects on nitrogen mineralization in freshly amended soil. Soil Science Society of American Journal, v.52, p.109-112, 1988.

LOGAN, T.J.; CHANEY, R.L. Utilization of municipal wastewater and sludge on land - Metals. In: PAGE, A.L.; GLEASON, T.L.; SMITH JR., J.E.; ISKANDAR, I.K.; SOMMERS, L.E. Proceedings of the 1983 workshop on utilization of municipal wastewater and sludge on land. Riverside: University of California, 1983, p.235323.

MCBRIDE, M.B.; RICHARDS, B.K.; STEENHUIS, T.; RUSSO, J.J.; SAUVÉ, S. Mobility and silubitity of toxic metals and nutrients in soil fiftenn years after sludge application. Soil Science, v. 162, n.7, p.487-500, 1997.

MARQUES, M.O. Efeitos da aplicação de lodo de esgoto na produtividade e qualidade da cana-de-açúcar. Piracicaba, 1990. 164p. Tese (Doutorado) - Escola Superior de Agricultura "Luiz de Queiroz", Universidade de São Paulo.

MATTIAZZO, M.E. Comportamento de cobre, cádmio, crômio, níquel e zinco adicionados a solos de clima tropical em diferentes valores de pH. Piracicaba, 1994. 197p. Tese (Livre Docência) - Escola Superior de Agricultura "Luiz de Queiroz", Universidade de São Paulo. 
MATTIAZZO-PREZOTTO, M.E. Química ambiental e agronomia. In: REUNIÃO BRASILEIRA DE FERTILIDADE DO SOLO E NUTRIÇÃO DE PLANTAS, 22. Piracicaba, 1992. Anais. Piracicaba: Fundação Cargill, 1992. p.157-178.

MATTIAZZO, M.E.; BARRETO, M.C.V.; RODELLA, A.A. Organic matter kinetics mineralization in soils amended with four diffrent organic wastes (compact disc). In: CONGRESS MONDIAL DE SCIENCE DU SOL, 16., Montpellier, 1998. Actes. Montpellier: ISSS, 1998.

MCNAB, W.A; BERRY,C.R. Distribuition of aboveground biomass in three pine species planted on a devastated site amended with sewage sludge or inorganic fertilizer. Forest Science, v.31, n.2, p.373-382, 1985.

MEDALIE, L.; BOWDEN, W.B.; SMITH, C.T. Nutrient leaching following land application of aerobically digested municipal sewage sludge in a Northern Hardwood Forest. Journal of Environmental Quality, V.23, p.130-138, 1994.

MEHLICH, A. Mehlich 3 soil test extractant: a modification of mehlich 2 extractant. Communications in Soil Science and Plant Analysis, v. 15, p. 1409-1416, 1984.

MELO, W.J.; MARQUES, M.O.; SANTIAGO, G.; CHELLI, R.A.; LEITE, S.A.S. Efeito de doses crescentes de lodo de esgoto sobre frações de matéria orgânica e CTC de um latossolo cultivado com cana-de-açúcar. Revista Brasileira de Ciência do Solo, v.18, p.449-455, 1994.

MELO, W.J.; MARQUES, M.O.; SILVA, F.C. da; BOARETTO, A.E. Uso de resíduos sólidos urbanos na agricultura e impactos ambientais (compact disc). In: CONGRESSO BRASILEIRO DE CIÊNCIA DO SOLO, 26., Rio de Janeiro, 1997. Anais. Rio de Janeiro: SBCS, EMBRAPA, 1997. 
MELO, W.J.; PEREIRA, M.L.; MURAOKA, T.; MARQUES, M.O.; MELO, G.M.P.; MELO, V.P. Efeito do lodo de esgoto, acrescido de cádmio, sobre plantas de sorgo cultivadas em latossolo. In: SEMINÁRIO SOBRE GERENCIAMENTO DE BIOSSÓLIDOS DO MERCOSUL, Curitiba, 1998. Anais. Curitiba: SANEPAR, ABES, 1998.

MISSELBROOK, T.H.; SHEPHERD, M.A.; PAIN, B.F. Sewage sludge applications to grassland: influence of sludge type, time and method of application on nitrate leaching and herbage yeld. Journal of Agricultural Science, v.126, n.3, p.343$352,1996$.

MULVANEY, R.L. Methods for determination of inorganic nitrogen in soil. In: SPARKS, D.L. (Ed.) Methods of Soil Analysis: Chemical Methods. Madison: ASSS, ASA, 1996. p.1125-1139.

NOVAIS, R.F.; BARROS, N.F.; NEVES, J.C.L. Nutrição mineral do eucalipto. In: BARROS, N.F.; NOVAIS, R.F. (Ed.). Relação solo-eucalipto. Viçosa: Editora Folha de Viçosa, 1990. cap. 1, p.25-98.

OLIVEIRA, F.C. Comportamento de metais pesados e formas nitrogenadas em solos tratados com lodo de esgoto. Piracicaba, 1995. 91p. Dissertação (Mestrado) Escola Superior de Agricultura "Luiz de Queiroz", Universidade de São Paulo.

OLIVEIRA, F.C.; MARQUES, M.O.; BELLINGIERI, P.A.; PERECIN, D. Lodo de esgoto como fonte de macronutrientes para a cultura do sorgo granífero. Scientia Agricola, v.52, n.2, p.360-367, 1995.

PIRES, A.M.M. Disponibilidade de $\mathrm{Zn}$ e $\mathrm{Cu}$ adicionados a solos via lodo de esgoto para plantas de arroz. Piracicaba, 1998. 55p. Dissertação (Mestrado) - Escola Superior de Agricultura "Luiz de Queiroz", Universidade de São Paulo. 
PHILLIPS, R.; FISHER, J.T.; MEXAL, J.G. Fuelwood production utilizing Pinus eldarica and sewage sludge fertilizer. Forest Ecology and Management, v.16, p.95-102, 1996.

POLGLASE, P.J.; MYERS, B.J. Tree plantations for recycling effluent and biosolids in Australia. In: PROCEEDINGS OF THE JOINT AUSTRALIAN/JAPONESE WORKSHOP HELD IN AUSTRALIA, 1., Sidney, 1995. Environmental management: The role of eucalypts and other fast growing species. Callingwood: CSIRO Publishing, 1996. p. 100-109.

PRESCOTT, C.E.; MCDONALD, M.A.; GESSEL, S.P.; KIMMINS, J.P. Long-term effects of sewage sludge and inorganic fertilizers on nutrient turnover in litter in a coastal Douglas fir forest. Forest Ecology and Management, v.59, p.149-164, 1993.

PURVES, D. Sources of trace element contamination of soils. In: PURVES, D. Trace element contamination of the environmental. Amsterdam: Elsevier Science Publishers, 1985, cap.4, p.66-98.

RAIJ, B. van; QUAGGIO, J.A. Métodos de análise de solo para fins de fertilidade. Campinas: IAC, 1983. 40 p. (IAC. Boletim Técnico, 81).

RAISON, R.J.; CONNEL, M.J.; KHANNA, P.K.; FALKINER, R.A. Effects of irrigation and nitrogen fertilization on fluxes of soil mineral nitrogen in a stand of Pinus radiata. Forest Ecology and Management, v.52, p.43-64, 1992.

SANTOS, H.F. dos; GUIMARÃES, M.O.; GIUSTI, P.E.A. Uso do lodo de ETEs em reflorestamentos. In: ENCONTRO TÉCNICO DA ASSOCIAÇÃO DE ENGENHEIROS DA SABESP, São Paulo, 1997. Anais. São Paulo: SABESP, 1997. p.1-23. 
SARRUGE, J.R.; HAAG, H.P. Análises químicas em plantas. Piracicaba: ESALQ, Depto. de Química, 1974. 56p.

SERNA, M.D.; POMARES, F. Indexes of assessing $\mathrm{N}$ avaiability in sewage sludges. Plant and Soil, v.139, p.15-21, 1992.

SHEPHERD, M.A. Factors affecting nitrite leaching from sewage sludges applied to a sandy soil in arable agriculture. Agriculture, Ecosystems and Environment, v.58, p.171-185, 1996.

SHUMAN, L.M. Effect of organic waste amendments on zinc adsorption by two soils. Soil Science, v.164, n.3, p.197-205, 1999.

SILVA, F.C. Uso agronômico de lodo de esgoto: efeitos em fertilidade do solo e qualidade da cana-de-açúcar. Piracicaba, 1995. 170p. Tese (Doutorado) - Escola Superior de Agricultura “Luiz de Queiroz", Universidade de São Paulo.

SOMMERS, L.E.; GIORDANO, P.M. Use of nitrogen from agricultural, industrial and municipal wastes. In: HAUCK, R.D. (Ed.). Nitrogen in crop production. Madison: ASA, 1984. p.208-218.

SOON, Y.K.; ABBOUD, S. Cadmium, chromium, lead and nickel. In: CARTER, M.R. Soil sampling and methods of analysis. Otawa: Canadian Society of Soil Science, 1993. cap.13, p.101-108.

U.S. ENVIRONMENTAL PROTECTION AGENCY 1983. EPA 625/1-83-016. Environmental regulations and tecnology: Land application of municipal sludge. Fed. Reg. p. 7-20. 
U.S. ENVIRONMENTAL PROTECTION AGENCY 1984. EPA 625/10-84-003. Environmental regulations and tecnology: Use and dispoal of municipal wastewater sludge. Fed. Reg. p. 15-16.

U.S. ENVIRONMENTAL PROTECTION AGENCY 1993. 40 CFR Parts 257, 403 and 503. Final rules: Standards for the use of sewage sludge. Fed. Reg. v.58, n.32, p.9248-9415.

WEETMAN, G.F.; MCDONALD, M.A.; PRESCOTT, C.E.; KIMMINS, J.P. Responses of western hemlock, pacific silver fir, and western red cedar plantations on northern Vancouver Island to applications of sewage sludge and inorganic fertilizer. Canadian Journal Fores. Res., v.23, p. 1815-1820, 1993.

ZHU, B.; ALVA, A.K. Trace metal and cation transport in a sandy soil with various amendments. Soil Science Society American Journal, v.57, n.3, p.723-727, 1993. 
APÊNDICES 
Apêndice 1 Valor de F, probabilidade $>\mathrm{F}$ e coeficiente de variação (C.V.) das análises de variância ${ }^{(1)}$ feitas à partir dos dados de Cu-trocável no solo, durante os primeiros 180 dias após aplicação do biossólido.

\begin{tabular}{|c|c|c|c|c|}
\hline Variável avaliada & Causa de variação & Valor de F & Probabilidade $>\mathrm{F}$ & C.V. \\
\hline \multirow[t]{3}{*}{ Cu-trocável no solo à $0-30 \mathrm{~cm}$} & Dose & 2,234 & 0,153 & 10,53 \\
\hline & Época & 0,843 & 0,518 & 21,08 \\
\hline & Dose $x$ época & 1,028 & 0,438 & $-\cdots$ \\
\hline \multirow[t]{3}{*}{ Cu-trocável no solo à $30-60 \mathrm{~cm}$} & Dose & 0,544 & 0,667 & 9,39 \\
\hline & Época & 4,417 & 0,009 & 13,94 \\
\hline & Dose $x$ época & 2,460 & 0.026 & --.-- \\
\hline \multirow[t]{3}{*}{ Cu-trocável no solo à $60-90 \mathrm{~cm}$} & Dose & 0,477 & 0.709 & 10,22 \\
\hline & Época & 3,264 & 0,032 & 19,77 \\
\hline & Dose $\mathrm{x}$ época & 0,415 & 0,918 & --.- \\
\hline
\end{tabular}


Apêndice 2 Valor de $\mathrm{F}$, probabilidade $>\mathrm{F}$ e coeficiente de variação (C.V.) das análises de variância ${ }^{(1)}$ feitas à partir dos dados de $\mathrm{N}-\mathrm{NO}_{3}{ }^{-}$no solo, durante os primeiros 180 dias após aplicação do biossólido.

\begin{tabular}{|c|c|c|c|c|}
\hline Variável avaliada & Causa de variação & Valor de F & Probabilidade $>F$ & C.V. \\
\hline \multirow[t]{3}{*}{$\mathrm{N}-\mathrm{NO}_{3}^{-1}$ no solo à $0-30 \mathrm{~cm}$} & Dose & 1,268 & 0,342 & 13,82 \\
\hline & Época & 4,887 & 0,006 & 98,24 \\
\hline & Dose $\mathrm{x}$ época & 0,061 & 0,100 & ---- \\
\hline \multirow[t]{3}{*}{$\mathrm{N}-\mathrm{NO}_{3}{ }^{-1}$ no solo à $30-60 \mathrm{~cm}$} & Dose & 0,561 & 0,657 & 42,58 \\
\hline & Época & 3,012 & 0,042 & 108,40 \\
\hline & Dose $x$ época & 0,234 & 0,986 & $-\cdots$ \\
\hline \multirow[t]{3}{*}{$\mathrm{N}-\mathrm{NO}_{3}{ }^{-1}$ no solo à $60-90 \mathrm{~cm}$} & Dose & 0,266 & 0,849 & 38,42 \\
\hline & Época & 9,397 & 0,0002 & 98,06 \\
\hline & Dose x época & 0,355 & 0,946 & -- \\
\hline
\end{tabular}

(1) Graus de liberdade: Bloco = 3; Dose de biossólido = 3; Resíduo A = 9; Parcelas = 15; Epocas = 3; Dose de biossólido $\mathrm{x}$ Época $=9 ;$ Residuo $\mathrm{B}=36$; Total $=63$. 
Apêndice 3 Valor de F, probabilidade $>\mathrm{F}$ e coeficiente de variação (C.V.) das análises de variância ${ }^{(1)}$ feitas à partir dos dados de metais no solo, 360 dias após aplicação do biossólido. Valores para a causa de variação "dose de biossólido".

\begin{tabular}{|c|c|c|c|}
\hline Variável avaliada & Valor de F & Probabilidade $>\mathrm{F}$ & C.V. \\
\hline Cu-trocável no solo à $0-10 \mathrm{~cm}$ & 3,600 & 0,059 & 30,12 \\
\hline Cu-trocável no solo à $10-20 \mathrm{~cm}$ & 1,667 & 0,242 & 30,77 \\
\hline Cu-trocável no solo à $20-30 \mathrm{~cm}$ & 1,941 & 0,193 & 18,98 \\
\hline Cu-trocável no solo à $30-60 \mathrm{~cm}$ & 1,320 & 0,327 & 21,50 \\
\hline $\mathrm{Cr}$-total no solo à $0-10 \mathrm{~cm}$ & 4,225 & 0,040 & 6,12 \\
\hline Cr-total no solo à $10-20 \mathrm{~cm}$ & 0,693 & 0,581 & 11,33 \\
\hline Cr-total no solo à $20-30 \mathrm{~cm}$ & 3,496 & 0,062 & 8,92 \\
\hline Cr-total no solo à $30-60 \mathrm{~cm}$ & 1,312 & 0,330 & 12,04 \\
\hline Cr-total no solo à $60-90 \mathrm{~cm}$ & 2,371 & 0,138 & 11,76 \\
\hline Cu-total no solo à $0-10 \mathrm{~cm}$ & 1,319 & 0,327 & 8,03 \\
\hline Cu-total no solo à $10-20 \mathrm{~cm}$ & 1,235 & 0,353 & 8,73 \\
\hline Cu-total no solo à $20-30 \mathrm{~cm}$ & 1,283 & 0,338 & 17,39 \\
\hline Cu-total no solo à $30-60 \mathrm{~cm}$ & 1,582 & 0,260 & 14,04 \\
\hline Cu-total no solo à $60-90 \mathrm{~cm}$ & 0,765 & 0,544 & 54,95 \\
\hline Zn-total no solo à $0-10 \mathrm{~cm}$ & 0,772 & 0,540 & 59,38 \\
\hline Zn-total no solo à $10-20 \mathrm{~cm}$ & 2,489 & 0,126 & 20,91 \\
\hline Zn-total no solo à $20-30 \mathrm{~cm}$ & 2,618 & 0,115 & 17,13 \\
\hline Zn-total no solo à $30-60 \mathrm{~cm}$ & 3,746 & 0,260 & 14,04 \\
\hline Zn-total no solo à $60-90 \mathrm{~cm}$ & 2,225 & 0,154 & 33,25 \\
\hline
\end{tabular}

- (1) Graus de liberdade: Bloco = 3; Dose de biossólido = 3; Resíduo = 9; Total = 15 . 
Apêndice 4 Valor de F, probabilidade $>\mathrm{F}$ e coeficiente de variação (C.V.) das análises de variância ${ }^{(1)}$ feitas à partir dos dados de $\mathrm{N}$ no solo, 360 dias após aplicação do biossólido. Valores para a causa de variação "dose de biossólido".

\begin{tabular}{|c|c|c|c|}
\hline Variável avaliada & Valor de F & Probabilidade $>\mathrm{F}$ & C.V. \\
\hline $\mathrm{N}^{-\mathrm{NO}_{3}}{ }^{-}$no solo à $0-10 \mathrm{~cm}$ & 1,881 & 0,203 & 77,53 \\
\hline $\mathrm{N}-\mathrm{NO}_{3}{ }^{-}$no solo à $10-20 \mathrm{~cm}$ & 1,412 & 0,302 & 62,78 \\
\hline $\mathrm{N}-\mathrm{NO}_{3}{ }^{-}$no solo à $20-30 \mathrm{~cm}$ & 0,833 & 0,514 & 92,34 \\
\hline $\mathrm{N}-\mathrm{NO}_{3}{ }^{-}$no solo à $30-60 \mathrm{~cm}$ & 3,081 & 0,083 & 70,61 \\
\hline $\mathrm{N}-\mathrm{NO}_{3}{ }^{-}$no solo à $60-90 \mathrm{~cm}$ & 1,022 & 0,429 & 58,64 \\
\hline N-total no solo à $0-10 \mathrm{~cm}$ & 0,622 & 0,621 & 18,04 \\
\hline N-total no solo à $10-20 \mathrm{~cm}$ & 0,504 & 0,692 & 23,24 \\
\hline N-total no solo à $20-30 \mathrm{~cm}$ & 0,283 & 0,837 & 15,09 \\
\hline N-total no solo à $30-60 \mathrm{~cm}$ & 0,863 & 0,970 & 9,71 \\
\hline N-total no solo à $60-90 \mathrm{~cm}$ & 0,899 & 0,519 & 45,25 \\
\hline
\end{tabular}

(1) Graus de liberdade: Bloco = 3; Dose de biossólido = 3; Resíduo = 9; Total = 15 .

Apêndice 5 Valor de $\mathrm{F}$, probabilidade $>\mathrm{F}$ e coeficiente de variação (C.V.) das análises de variância ${ }^{(1)}$ feitas à partir dos dados de folha, 360 dias após aplicação do biossólido. Valores para a causa de variação "dose de biossólido".

\begin{tabular}{cccc}
\hline Variável avaliada & Valor de F & Probabilidade $>\mathrm{F}$ & C.V. \\
\hline Cu nas folhas de $E$. grandis & 0,236 & 0,869 & 15,80 \\
Ni nas folhas de $E$. grandis & 0,537 & 0,671 & 158,86 \\
Zn nas folhas de $E$. grandis & 2,785 & 0,102 & 86,51 \\
N nas folhas de $E$. grandis & 15,487 & 0,001 & 6,25 \\
\hline
\end{tabular}

(ग) Graus de liberdade: Bloco = 3; Dose de biossólido = 3; Resíduo = 9; Total = 15 . 